\title{
Tropospheric ozone over Equatorial Africa: regional aspects from the MOZAIC data
}

\author{
B. Sauvage, V. Thouret, J.-P. Cammas, F. Gheusi, G. Athier, and P. Nédélec \\ Laboratoire d'Aérologie, OMP, UMR 5560, Toulouse, France \\ Received: 9 April 2004 - Published in Atmos. Chem. Phys. Discuss.: 21 June 2004 \\ Revised: 24 November 2004 - Accepted: 27 January 2005 - Published: 7 February 2005
}

\begin{abstract}
We analyze ozone observations recorded over Equatorial Africa between April 1997 and March 2003 by the MOZAIC programme, providing the first ozone climatology deriving from continental in-situ data over this region. Threedimensional streamlines strongly suggests connections between the characteristics of the ozone monthly mean vertical profiles, the most persistent circulation patterns in the troposphere over Equatorial Africa (on a monthly basis) such as the Harmattan, the African Easterly Jet, the Trades and the regions of ozone precursors emissions by biomass burning. During the biomass burning season in each hemisphere, the lower troposphere exhibits layers of enhanced ozone (i.e. 70 ppbv over the coast of Gulf of Guinea in December-February and 85 ppbv over Congo in June-August). The characteristics of the ozone monthly mean vertical profiles are clearly connected to the regional flow regime determined by seasonal dynamic forcing. The mean ozone profile over the coast of Gulf of Guinea in the burning season is characterized by systematically high ozone below $650 \mathrm{hPa}$; these are due to the transport by the Harmattan and the AEJ of the pollutants originating from upwind fires. The confinement of high ozone to the lower troposphere is due to the high stability of the Harmattan and the blocking Saharan anticyclone which prevents efficient vertical mixing. In contrast, ozone enhancements observed over Central Africa during the local dry season (June-August) are not only found in the lower troposphere but throughout the troposphere. Moreover, this study highlights a connection between the regions of the coast of Gulf of Guinea and regions of Congo to the south that appears on a semi annual basis. Vertical profiles in wet-season regions exhibit ozone enhancements in the lower troposphere due to biomass burning products transport from fires situated in the opposite dry-season hemisphere.
\end{abstract}

$\overline{\text { Correspondence to: } \text { B. Sauvage }}$

(saub@aero.obs-mip.fr)

\section{Introduction}

Tropospheric ozone acts both to control the oxidizing capacity of the atmosphere and as a greenhouse gas (Logan and Kirchhoff, 1986; Crutzen, 1987). Most of the oxidation of long-lived gases by hydroxyl radicals $(\mathrm{OH})$ takes place in the tropics, where high UV and humidity promote the formation of OH from the photolysis of ozone (Logan et al., 1981; Thompson, 1992). Ozone is produced within the troposphere by the photochemical oxidation of hydrocarbons, methane $\left(\mathrm{CH}_{4}\right)$ and carbon monoxide $(\mathrm{CO})$ in the presence of nitrogen oxides $\left(\mathrm{NO}_{\mathrm{x}}=\mathrm{NO}+\mathrm{NO}_{2}\right)($ Crutzen, 1974, 1988; Fishman et al., 1979; Marenco et al., 1989) and is also transported down from the stratosphere. Ozone photochemical formation occurs in three main ways (Logan et al., 1981, 1985): (1) a rapid formation from reactive hydrocarbons (urban pollution, biomass burning) close to their source, followed by its mixing within the troposphere, and (2) a slow and delayed formation ( 2 or 3 weeks) from less reactive precursors, such as $\mathrm{CO}$ and $\mathrm{CH}_{4}$, during or after their redistribution in the troposphere by horizontal and vertical atmospheric motions (Logan et al., 1981, 1985). This has been summarized as "cook then mix" or "mix then cook" by Chatfield and Delany (1990). (3) A very slow process of production in the uppermost troposphere which results from background tropospheric carbon species and nitrogen oxides. The latter process can be accelerated by lightning $\mathrm{NO}_{\mathrm{x}}$ as the dry season gives way to thunderstorms of the wet season (Edwards et al., 2003; Chatfield et al., 2004). While this appears to be a non-pollution process, the organic radical producers may indeed be increased by pollution.

The first rapid process is illustrated by polluted biomass burning plumes sampled during the TROPOZ campaign showed that ozone concentrations increase from 90 to 105 ppbv after only two days (Jonquieres et al., 1998). Thus the photochemical impact of pollutants must be considered both on regional and hemispheric scales.

(C) 2005 Author(s). This work is licensed under a Creative Commons License. 

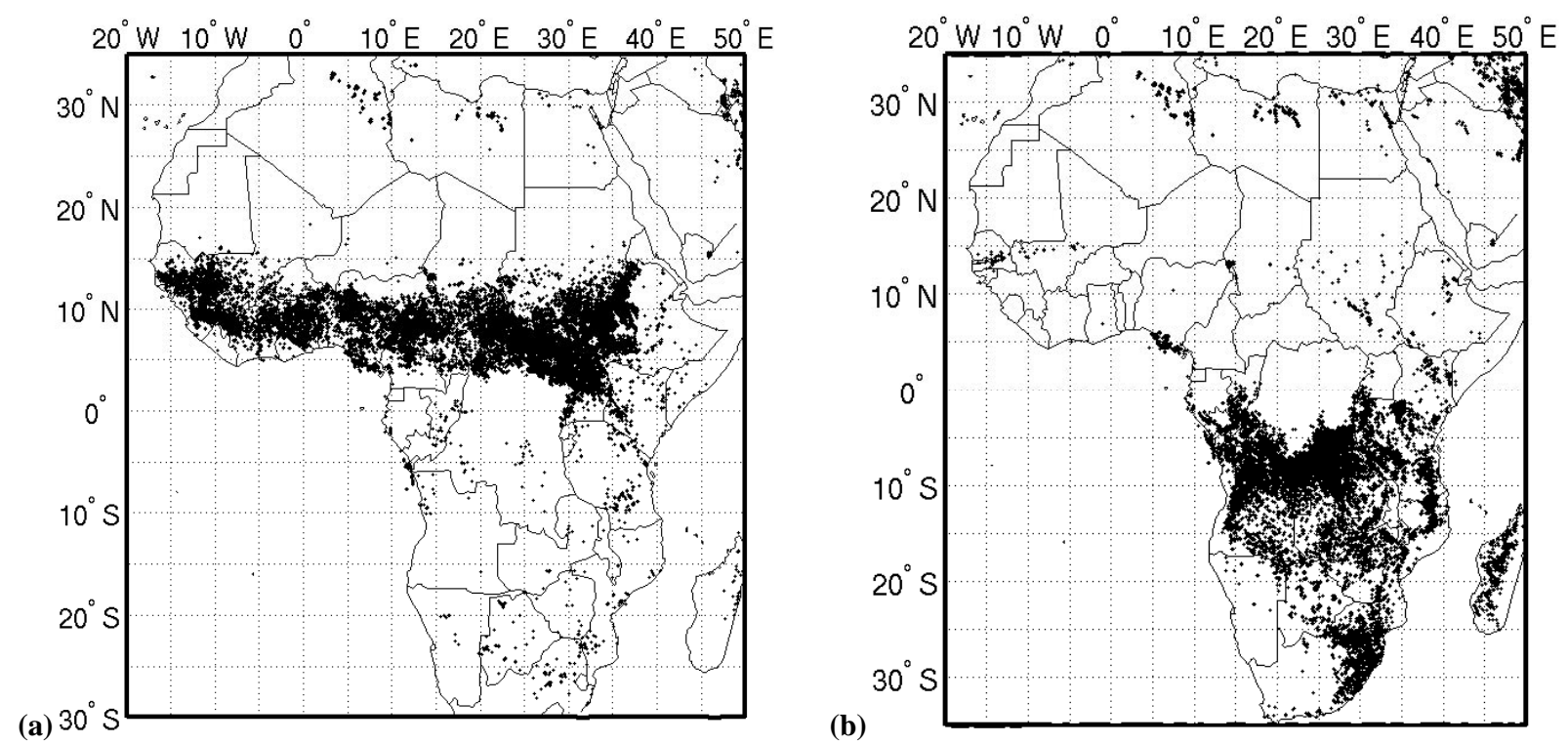

Fig. 1. Fires counts during DJF (a) and JJA (b) from the ATSR World fire Atlas (http://shark1.esrin.esa.it/ionia/FIRE/). Average over the years 1998 to 2002 .

The equatorial African region is of great interest because of a particular combination of dynamical processes, high chemical activity from intense biomass burning. Figure 1 shows the position of the fires as seen by ATSR on board of ERS2, and averaged over the years 1998-2002, for the two dry seasons.

We begin with a schematic overview of the dynamical situation over Africa for two opposite seasons. Figure 2 shows an example of the monthly mean streamlines from the ECMWF analyses for January and July 2002 (left and right column respectively), for three different pressure levels $(250 \mathrm{hPa}$ : a and b; $650 \mathrm{hPa}$ : $\mathrm{c}$ and $\mathrm{d}$; and $850 \mathrm{hPa}$ : e and f). One of the main synoptic flow features is the West African monsoon; a flow from the south-west due to the strong thermal gradient between continent and ocean in boreal summer (Fig. 2f). The zone of confluence between north-easterly (Harmattan) and south-westerly trade winds is represented by the intercontinental convergence zone (hereafter, ITCZ, Figs. 2e, f, red lines) which shifts each boreal summer into the northern hemisphere. The African Easterly Jet (hereafter, AEJ) is a thermal wind responding to temperature gradients between the warm Sahara Desert area and the cool Gulf of Guinea in southern West Africa. It is located around 700$650 \mathrm{hPa}$ (Fig. 2c). The equatorward side of the jet coincides with maximum cyclonic shear and may also be the birthplace of easterly waves which reach their maximum from May to October. Two anticyclones dominate at $500 \mathrm{hPa}$. The Saharan Anticyclone is centered at $15^{\circ} \mathrm{N}-10^{\circ} \mathrm{E}$; and the South Atlantic Subtropical Anticyclone (hereafter SASTA, or St. Helena anticyclone) is centered at $30^{\circ} \mathrm{S}-15^{\circ} \mathrm{W}$ (at $850 \mathrm{hPa}$ level for both, Fig. 2e and f). These two highs migrate syn- chronously of the ITCZ, with a northward shift during the monsoon season (JJA). They both contribute to the well defined and stable trade-wind inversion and the highly stratified nature of the atmosphere (Andreae et al., 1994). Compared with West Africa, East Africa exhibits slightly different regimes due to the topography and the proximity of the Indian Ocean. Several major structural elements can be identified: the ITCZ and the Arabian and Mascarene anticyclones. The East African low-level jet or Somali jet (Fig. 2f), originates at the north-eastern tip of Madagascar (Hastenrath, 1990); and the Tropical Easterly Jet prevails in the upper troposphere.

In Africa as a whole, the forest and the savannas occupy areas of $2 \times 10^{6}$ and $1 \times 10^{7} \mathrm{~km}^{2}$, respectively. The annually burned dry matter biomass is estimated at $1.3 \times 10^{8}$ tons $\mathrm{yr}^{-1}$ (Delmas et al., 1991). Human activities are the primary cause of biomass burning, which serves a variety of purposes: clearing of forest and brush land for agricultural use, conversion of forests to agricultural and pastoral uses, energy production for cooking, heating and fuel, control of pests, insects and weeds, nutrient mobilization, and removal of brush and litter (Crutzen and Andreae, 1990). Biomass burning has long been recognized as a significant source of reactive species such as $\mathrm{CO}$, hydrocarbons and $\mathrm{NO}_{\mathrm{x}}$, which play an important role in the chemistry and the radiative budget of the troposphere (Crutzen et al., 1985; Crutzen and Andreae, 1990). Emissions of ozone precursors from biomass burning and their consequent photochemistry have been observed at different scales (Andreae et al., 1988, 1992; Marenco et al., 1990; Fishman et al., 1990; Jonquieres et al., 1998). 

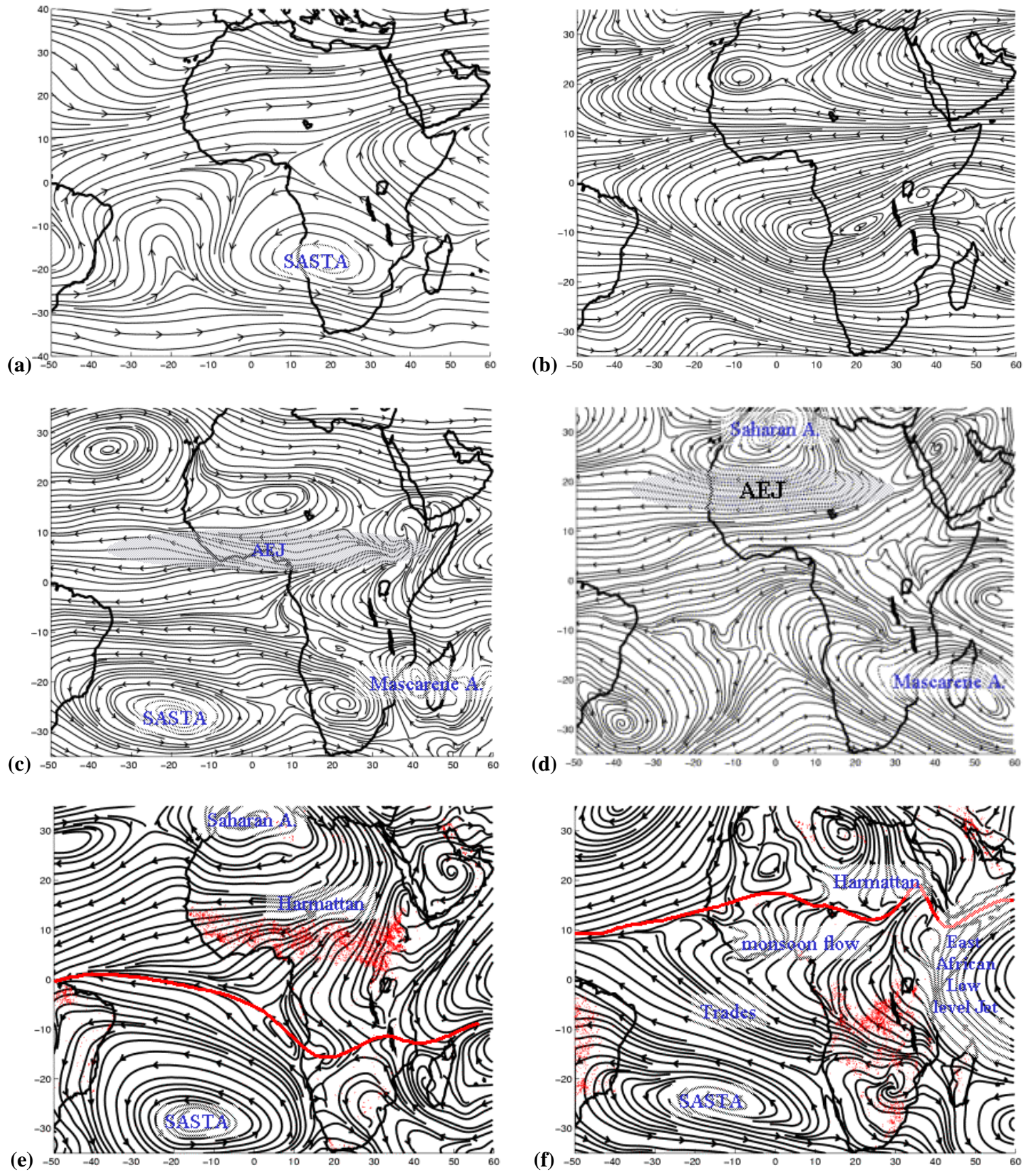

Fig. 2. Monthly mean streamlines from the 2002 ECMWF analyses. (a) $250 \mathrm{hPa}$ January, (b) $250 \mathrm{hPa}$ July; (c) $650 \mathrm{hPa}$ January; (d) $650 \mathrm{hPa}$ July; (e) $850 \mathrm{hPa}$ Januray; (f) $850 \mathrm{hPa}$ July. Main dynamical features are written in blue. ITCZ is represented by a red doted line. Red points symbolize the position of the fires in January and July (as in Fig. 1). Shaded areas symbolize the AEJ location.

However Africa remains a poorly understood and documented continent. Several campaigns have been conducted within the last decades to learn more about emissions and transport of biogenic and anthropogenic trace constituents over the South Atlantic and Africa (Table 1 and references therein). These field missions focused mainly on emis- sions from tropical ecosystems and on the photochemistry of lower and middle troposphere. The first results came from DECAFE (1988 - Congo), FOS/DECAFE (1991 Ivory Coast) followed by EXPRESSO (1996 Central Africa); and SAFARI/TRACE-A (1992-2000 Southern Africa). They provided evidence of biomass burning emissions over Africa. 
Table 1. Major African campaigns wich provided in-situ ozone measurements.

\begin{tabular}{|c|c|c|}
\hline Acronym & Publication (Special issues; papers) & Period/Place \\
\hline TROPOZ I and II & [J. Geophys. Res., 103 (D15), & 11-22 Dec. 1987 West Africa \\
\hline $\begin{array}{l}\text { "TROPospheric OZone } \\
\text { experiment" }\end{array}$ & Jonquieres et al., 1998] & 9 January to 1 February 1991 \\
\hline DECAFE & [J. Geophys. Res., 97 (D6), 1992] & February 1988 Congo \\
\hline "Dynamique Et Chimie & special issue "FOS/DECAFE 91 & Northern Hemisphere Dry season \\
\hline Atmosphérique en Forêt & Experiment" in J. Atmos. Chem., & 1991 Ivory Coast \\
\hline Equatoriale" & $22(1,2), 1-239,1995$ & \\
\hline FOS/DECAFE & [Fontan et al., 1992] & \\
\hline SAFARI-92/TRACE-A & [J. Geophys. Res., 101 (D19), 1996] & South Africa \\
\hline "Transport and Atmospheric & [Fishman et al., 1996] & $21-09-1992$ to $26-10-1992$ \\
\hline Chemistry near the Equator-Atlantic" & [Lindesay et al., 1996] & \\
\hline SAFARI-2000 & [South African J. of Sci., & August-September 1999 and 2000 \\
\hline "Southern African & $98,2002]$ & Southern Hemisphere Dry season \\
\hline Regional Science Initiative" & special issue, J. Geophys. Res., 108 (D13), 2003 & Zambia (Lusaka) \\
\hline \multirow[t]{2}{*}{ Polastern cruises } & [1987, 1988; Smit et al.,] & \\
\hline & 1989; Weller et al., 1996] & \\
\hline \multirow[t]{2}{*}{ Aerosols 99 cruise } & [Thompson et al., 2000] & January February 1999 \\
\hline & & $\begin{array}{l}\text { Northern Hemisphere Dry season } \\
\text { (New York City Cape Town) }\end{array}$ \\
\hline SHADOZ & [Thompson et al., 2002] & from 1998 on. once a week \\
\hline "Southern Hemisphere & & Nairobi (over Africa) \\
\hline \multicolumn{3}{|l|}{ ADditional Ozonesondes" } \\
\hline EXPRESSO & [Cautenet et al., 1999] & November 1996 to December 1996 \\
\hline Part of DECAFE programme & [Delmas et al., 1999] & Central Africa \\
\hline
\end{tabular}

High concentrations of gases $\left(\mathrm{CO}, \mathrm{CO}_{2}, \mathrm{NMHC}, \mathrm{NO}\right.$ and $\mathrm{O}_{3}$ ) and particles were observed in biomass burning plumes and haze layers occurring in the mid-troposphere (altitudes between 1 and $4 \mathrm{~km}$ ) (Andreae et al., 1988, 1992). The role of the ITCZ in the redistribution of carbon monoxide from biomass burning near Central Africa has been demonstrated by Cautenet et al. (1999). However, only a few measurements were made throughout the troposphere. The few ones performed during the TROPOZ I and II campaigns confirmed that fires in northern Equatorial Africa are effective in producing large amounts of ozone with photochemical ozone formation rates of $15-35 \mathrm{ppbv} \mathrm{O}_{3} . \mathrm{d}^{-1}$ in the middle troposphere (Jonquieres et al., 1998). During the SAFARI 2000 experiment, the flux of organic and elemental carbon from African savannas burning was estimated at $14 \pm 1 \mathrm{Tg} . \mathrm{yr}^{-1}$, and the flux of nitrogen species at $2 \pm 2 \mathrm{Tg}_{\mathrm{yr}}{ }^{-1}$ with much of this pollution exported from the east coast towards the Indian Ocean (Swap et al., 2003).

From a climatological point of view, observations of ozone over Africa are only available from satellite observations (TOMS) that can be interpreted to give a total tropospheric column ozone (Fishman and Brackett, 1997; Kim et al., 2001). There is however significant uncertainty in the tropospheric ozone columns products because of the very poor sensitivity of sensors to the lower troposphere ozone, presumably due to Rayleigh scattering. Even the recent TOMS product using the Scan-Angle Method overestimates clearsky tropospheric ozone columns in areas with particular low ozone and underestimates amounts in areas with high ozone (Kim et al., 2001). Indeed the TOMS Tropical Tropospheric Ozone Content (TTOC) do not capture the seasonal maximum due to biomass burning found in observations and models over sub-Saharan northern Africa (Thompson et al., 2002; Martin et al., 2002). This insensitivity in the lower troposphere increases the "tropical Atlantic paradox" (Thompson et al., 2000), i.e. the north-south gradient reversal in ozone over the tropical Atlantic during the northern African biomass burning season in December-February (DJF).

The lack of in-situ tropospheric measurements over Equatorial Africa restricts the assessment of its regional budget and validation of both global models and satellite products. The objective of this paper is to establish a climatology of tropospheric ozone (in terms of seasonal and vertical variations) over Equatorial Africa from the first regular insitu data recorded there by the MOZAIC programme. The MOZAIC programme and the methodology will be described in Sect. 2. In accord with the climatological approach of this paper we present the data merged by region and season so as 


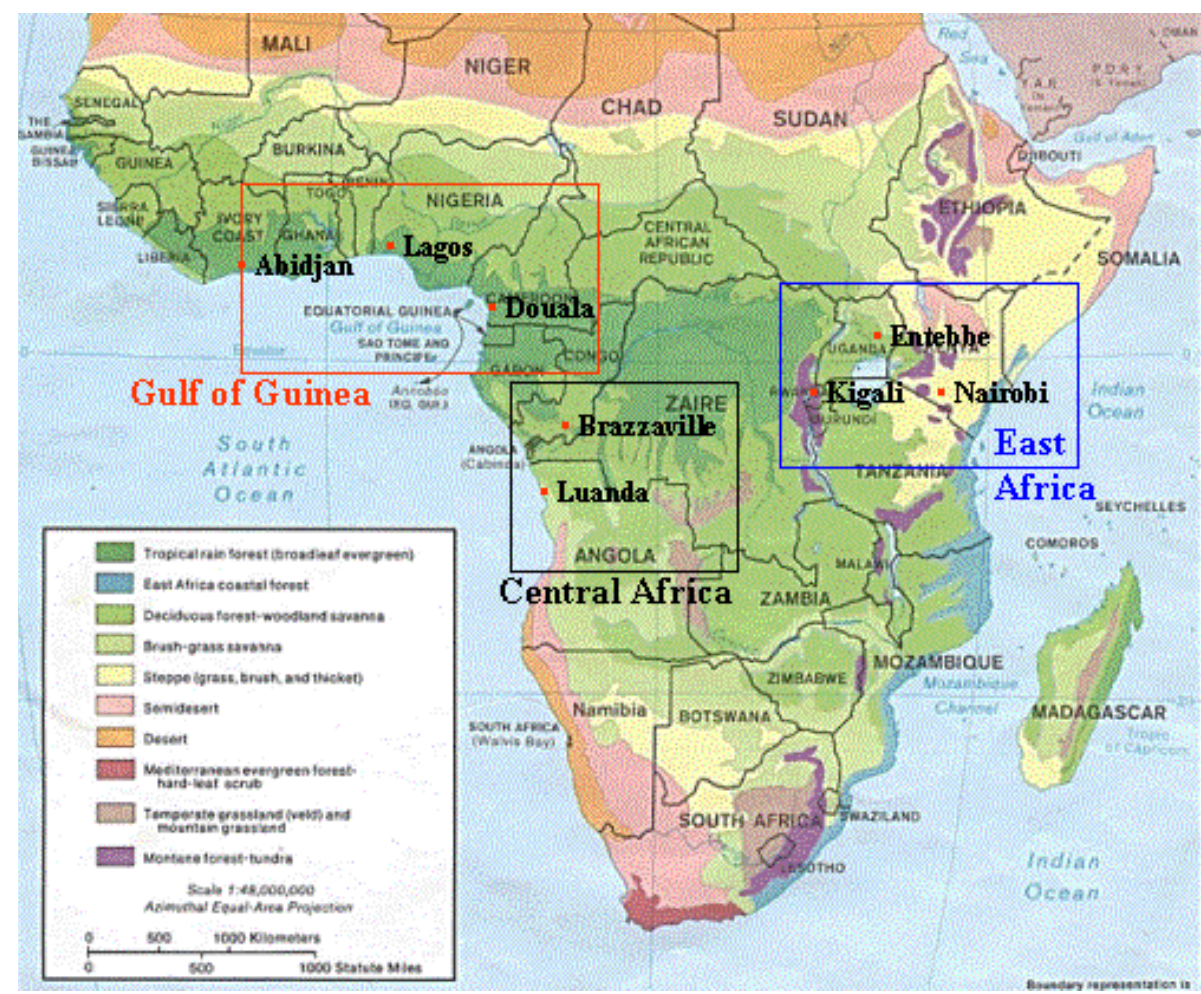

Fig. 3. Location of the most documented airports in the three different regions as defined in the text, along with the different vegetation type.

order to produce a catalogue of monthly mean vertical profiles. Our analysis in Sect. 3 further investigates the vertical distributions of a set of descriptors, i.e. biomass burning periods, meteorology particularities, vegetation, etc. The ozone monthly mean distributions presented here exhibit persistent and repetitive characteristics. We aim to establish connections between these characteristics and the most persistent circulation patterns in the troposphere over Equatorial Africa, such as the Harmattan, the AEJ and the Trades that have a weak variability in terms of location, on a monthly basis. For that purpose we have examined back-trajectories based on ECMWF monthly mean analyses, corresponding to 3-dimensional streamlines of a stationary flow, so as to investigate such connections.

\section{Data and Methodology}

The MOZAIC programme (Measurement of Ozone and Water Vapor by Airbus In-Service Aircraft) was designed to collect ozone and water vapour data, using automatic equipment installed aboard 5 long range Airbus A340 aircraft flying regularly all over the world (Marenco et al., 1998; http://www.aero.obs-mip.fr/mozaic/ for more details concerning access and use). The programme started in 1994, and more than 20000 flights have been already performed. The MOZAIC programme provides measurements every 4 seconds for ozone, water vapour, temperature and wind. The vertical take-off speed of the aircraft is around $5-7 \mathrm{~m} \mathrm{~s}^{-1}$, leading to a vertical resolution of the data of about 20 $28 \mathrm{~m}$. For ozone a dual-beam UV absorption instrument (Thermo-Electron, model 49-103) is used, and the measurement accuracy was estimated at $\pm 2 \mathrm{ppbv}+2 \%$; details are given in Thouret et al. (1998b). An inter-comparison with the available ozone soundings has shown the ability of the MOZAIC ozone data to produce accurate and reliable ozone distributions (Marenco et al., 1998; Thouret et al., 1998b; http://www.aero.obs-mip.fr/mozaic/). Since the end of 2001, MOZAIC has also provided additional measurements of $\mathrm{NO}_{\mathrm{y}}$ on board only 1 aircraft, (Volz-Thomas et al., 2004) and CO on board all 5 aircraft (Nédélec et al., 2003). The data set used for this analysis corresponds to measurements of ozone and water vapour recorded between April 1997 and March 2003. We also make a specific use of the CO data recorded in January 2002 and January 2003 over Lagos.

In this paper, we use vertical profiles corresponding to takeoff and landing at 8 airports regularly visited by MOZAIC aircraft. Airports have been merged into 3 groups regarding their geographical position: Gulf of Guinea (Abidjan, Douala and Lagos), Central Africa (Brazzaville and Luanda), and East Africa (Entebbe, Kigali, Nairobi). Figure 3 shows their locations on a map. 

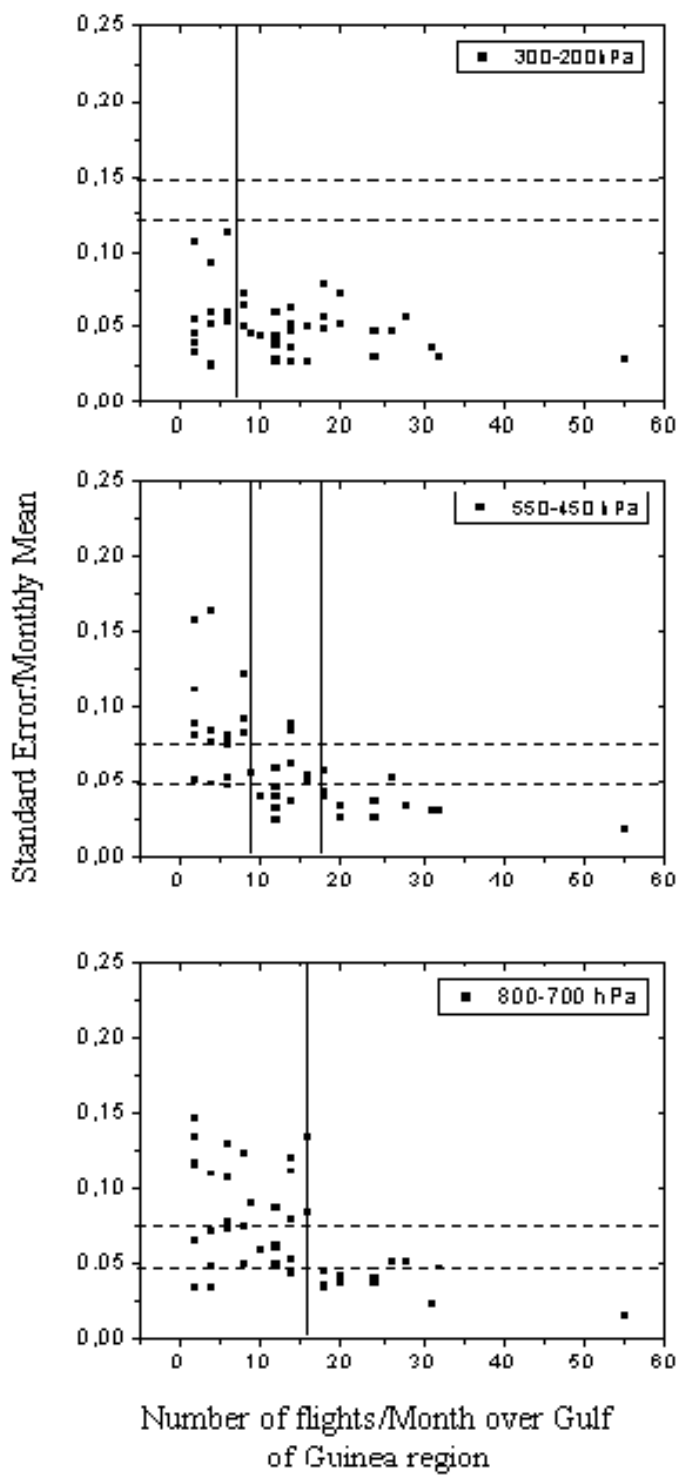

Fig. 4. Fractional standard error versus the number of flights in a month, for the pooled data over the Gulf of Guinea region. The horizontal dashed lines are for relative standard errors of 0.05 and 0.075 for the lower and the middle troposphere (800-700 and 550$450 \mathrm{hPa}$, respectively), and for 0.125 and 0.15 for the upper troposphere. Each point is the value for a given station and given month, for one of the indicated pressure level.

To study monthly mean distributions, ozone concentrations have been vertically averaged into 20 layers, 12 between the surface and $400 \mathrm{hPa}$ with a $50 \mathrm{hPa}$ thickness and 8 between $400 \mathrm{hPa}$ and $200 \mathrm{hPa}$ with a $25 \mathrm{hPa}$ thickness. This resolution is fine enough to assess the general characteristics of the monthly mean distributions. We consider the aircraft measurements during ascent and descent to be vertical profiles even though there is significant $(350 \mathrm{~km})$ horizontal travel between the ground and cruising altitude. Com- parisons with ozonesondes (which ascend more steeply than aircraft) (Thouret et al., 1998a) and lidar (which provides a two-dimensional coverage of layers) (Stoller et al., 1999) have shown that the assumption is satisfactory. Table 2 gives the number of profiles available over Equatorial Africa since April 1997 as a total and per month. Note that each region is well documented throughout the year (except East Africa from February to April).

In order to determine a reliable climatology over equatorial Africa, we need to assess the statistical significance of our observations. The methodology is based on statistical laws, like in Logan (1999) with ozonesondes data. Figure 4 gives the standard error on the ozone monthly mean ( $\mathrm{SE}=\sigma / \sqrt{ } N$, with $\sigma$ the square root of the sample variance and $N$ the number of flights) as a fraction of the monthly mean versus the number of flights per month. The $95 \%$ confidence intervals for the monthly means (2SE) clearly depend on both the inherent variability of ozone and the number of measurements. Logan (1999) found that in the tropics, 20 ozone soundings were required for $1 \mathrm{SE}$ to be $<7.5 \%$ of the mean below $500 \mathrm{hPa}$.

Applying this criterion (the $95 \%$ confidence interval) to our data set shows that only 15 measurements are required in the lower troposphere (LT) over Gulf of Guinea for $1 \mathrm{SE}$ to be $<5 \%$ of the mean. In the mid troposphere (MT), 18 measurements are necessary for $1 \mathrm{SE}$ to be $<5 \%$ and 8 for $1 \mathrm{SE}<7.5 \%$. This value falls to 6 measurements in the upper middle troposphere, for $1 \mathrm{SE}$ to be $<12.5 \%$ of the mean, as the variability of ozone at this altitude is weaker in the tropics than mid-latitudes due the higher tropopause height that reduces the stratospheric influence. For the other regions (not shown) the variability is similar for each tropospheric level and within the sites. However fewer measurements are necessary for the LT and MT over Central Africa, with 12 and 7 measurements for $1 \mathrm{SE}<5 \%$ respectively. For Central Africa in the UT, 6 measurements are required, for $1 \mathrm{SE}<5 \%$. This clearly shows the different degrees of variability seen over Africa. The tropical region is known to be of high tropospheric ozone variability as recently shown by Thompson et al. (2003b). However, these results show that the ozone monthly means over each airport should be representative with 15 measurements over Gulf of Guinea, 13 over East Africa and 8 over Central Africa. Over the main visited cities (Brazzaville, Lagos, Abidjan), these criteria are satisfied (Table 2).

As introduced before we aim to establish connections between the ozone monthly mean vertical profiles characteristics and the main transport processes that also have a persistent signature on a monthly basis. One approach could have been to use seasonal streamlines at constant pressure level, averaged over the MOZAIC sampling period (1997-2003), as performed in similar studies (Jenkins and Ryu, 2004b for example). However, this approach only gives a two dimensional vision of the transport. We aim to further document the preferred pathways associated with the main dynamical 
Table 2. Number of MOZAIC profiles per month over Africa, from April 1997 to March 2003.

\begin{tabular}{|c|c|c|c|c|c|c|c|c|c|c|c|c|}
\hline AFRICA & & & & & & & & & & & & \\
\hline Town/Month & Jan. & Feb. & Mar. & Apr. & May & Jun. & Jul. & Aug. & Sep. & Oct. & Nov. & Dec. \\
\hline $\begin{array}{l}\text { Abidjan } \\
\text { Ivory Coast, } 5.4^{\circ} \mathrm{N} / 4^{\circ} \mathrm{W}\end{array}$ & 32 & 12 & 12 & 18 & 6 & 12 & 16 & 14 & 8 & 26 & 18 & 6 \\
\hline $\begin{array}{l}\text { Douala } \\
\text { Cameroon, } 4^{\circ} \mathrm{N} / 9.8^{\circ} \mathrm{E}\end{array}$ & 8 & 24 & 31 & 4 & - & - & - & - & 2 & 6 & 9 & - \\
\hline $\begin{array}{l}\text { Lagos } \\
\text { Nigeria, } 6.6^{\circ} \mathrm{N} / 3.3^{\circ} \mathrm{E}\end{array}$ & 14 & 28 & 20 & 55 & 12 & 2 & 14 & 16 & 4 & 24 & 20 & 10 \\
\hline GULF OF GUINEA & 54 & 64 & 53 & 77 & 18 & 14 & 30 & 30 & 14 & 56 & 47 & 16 \\
\hline $\begin{array}{l}\text { Brazzaville } \\
\text { Congo, } 4.3^{\circ} \mathrm{S} / 15.3^{\circ} \mathrm{E}\end{array}$ & 7 & 16 & 6 & 10 & 9 & 12 & 18 & 12 & 14 & 8 & - & - \\
\hline $\begin{array}{l}\text { Luanda } \\
\text { Angola, } 8.8^{\circ} \mathrm{S} / 13.3^{\circ} \mathrm{E}\end{array}$ & 6 & - & 2 & 8 & 5 & 1 & 10 & 4 & 4 & 4 & 2 & 2 \\
\hline CENTRAL AFRICA & 13 & 16 & 8 & 18 & 14 & 13 & 28 & 22 & 18 & 12 & 2 & 2 \\
\hline $\begin{array}{l}\text { Entebbe } \\
\text { Uganda, } 0^{\circ} \mathrm{N} / 32.4^{\circ} \mathrm{E}\end{array}$ & 2 & - & - & - & 8 & 4 & 8 & 12 & 6 & 7 & 2 & - \\
\hline $\begin{array}{l}\text { Kigali } \\
\text { Rwanda, } 2^{\circ} \mathrm{S} / 30.1^{\circ} \mathrm{E}\end{array}$ & - & - & - & - & 10 & 10 & 8 & 12 & 14 & 6 & 2 & 2 \\
\hline $\begin{array}{l}\text { Nairobi } \\
\text { Kenya, } 1.1^{\circ} \mathrm{S} / 36.7^{\circ} \mathrm{E}\end{array}$ & 2 & - & - & - & 18 & 14 & 16 & 24 & 20 & 14 & 4 & 2 \\
\hline EAST AFRICA & 4 & & & & 36 & 28 & 32 & 48 & 40 & 27 & 8 & 4 \\
\hline Total & 71 & 84 & 79 & 113 & 80 & 57 & 114 & 106 & 76 & 109 & 59 & 28 \\
\hline
\end{tabular}

processes and to link them with the vertical structure of ozone monthly mean distributions. For that purpose we have computed back-trajectories with the Lagrangian-model, LAGRANTO (Wernli and Davies, 1997; Wernli, 1997) using the 3-dimensional winds from the ECMWF monthly mean analyses $\left(0.5^{\circ} \times 0.5^{\circ}\right.$ latitude longitude grid, 60 vertical model levels) calculated with a time step of $30 \mathrm{~min}$. As is typical of these lagrangian approaches convection and turbulence are not represented in these calculations. Furthermore, monthly analyses only provide stationary wind fields, and hence trajectories computed here actually represent three-dimensional streamlines (hereafter 3-D streamlines).

As a validation, the robustness of this methodology has been assessed by a statistical comparison between 3-D streamlines and individual backtrajectories computed with 6-hourly ECMWF analyses. This comparison has been carried out for an ensemble of air parcels histories for which the sub-monthly variability of dynamical fields is included by defining the following set of initial parameters for backward movement computations over 5 days:

- the region defined by a $1.5^{\circ} \times 1.5^{\circ}$ latitude-longitude square centered around one of the airports visited by the MOZAIC aircraft (as the analyses have a $0.5^{\circ}$ horizontal resolution, such a $1.5^{\circ} \times 1.5^{\circ}$ square corresponds to air parcels defined by $4 \times 4$ grid points over the region)

- the pressure level choosen among mandatory level of ECMWF analyses
- the date of initialisation for four different years (2000, 2001, 2002, 2003); months of January and July; and for which the day is one of the following: the 30th, the 27th, 25th, 22nd and 20th of each month. (Limitations in varying the year and the day are due to data storage restrictions)

The robustness of the 3-D streamlines is established in terms of their ability to reproduce the same connections (between regions of fires and regions of ozone enhancements) as those established with backtrajectories. Connections with both approaches are quantified as the number of air parcels that passed over a selected source region of biomass burning products (compared to the initial number of air parcels released) following a particular direction. Thus we define selection criteria $(S C)$ as a combination of:

- a continental source region, geographically defined with the map of fires (Fig. 1)

- a pressure level dependence (characteristic of the altitude of the Harmattan, the Trades or the AEJ).

Note that the year of the ECMWF monthly mean analyses chosen for the 3-D streamlines simply fits with the year of the most frequent sampling by MOZAIC aircraft (depending on the region and the season). The investigation of the interannual variability of ozone monthly means and its possible dependence on one of dynamical fields is out of the scope of the present study. 


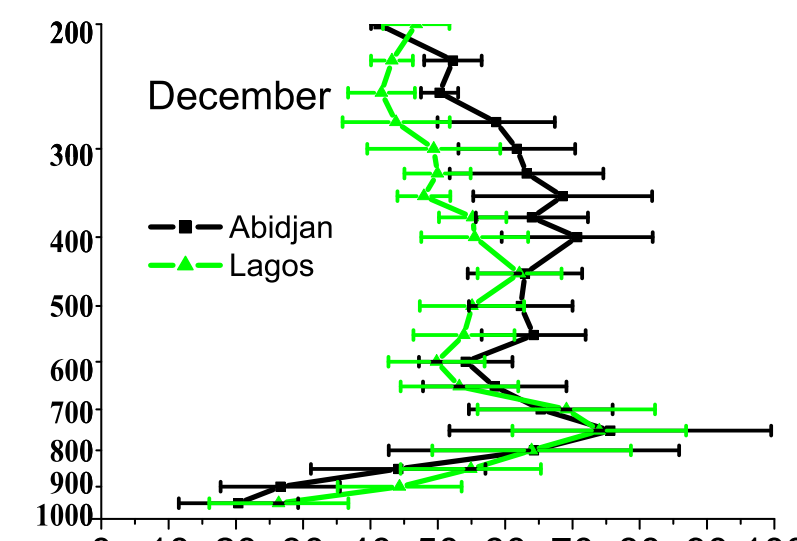

(a)
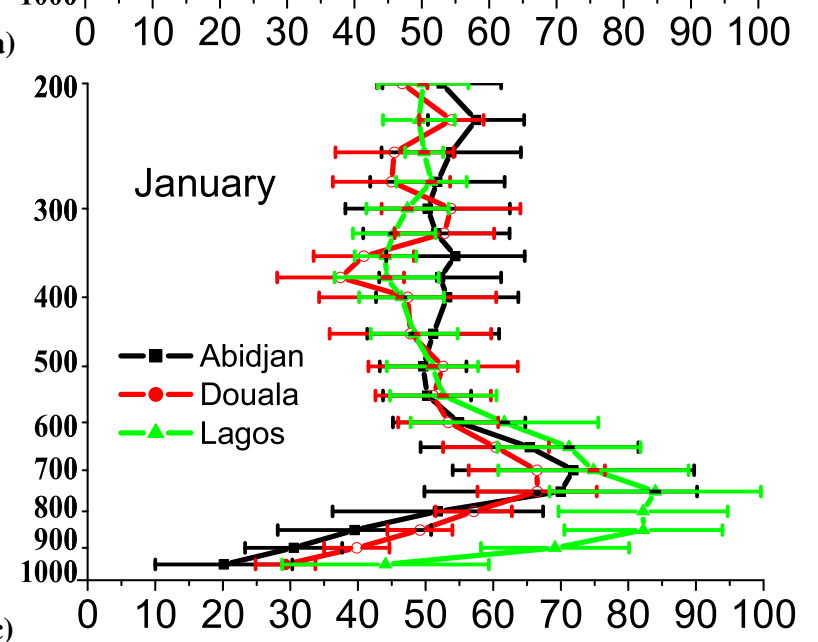

(b)
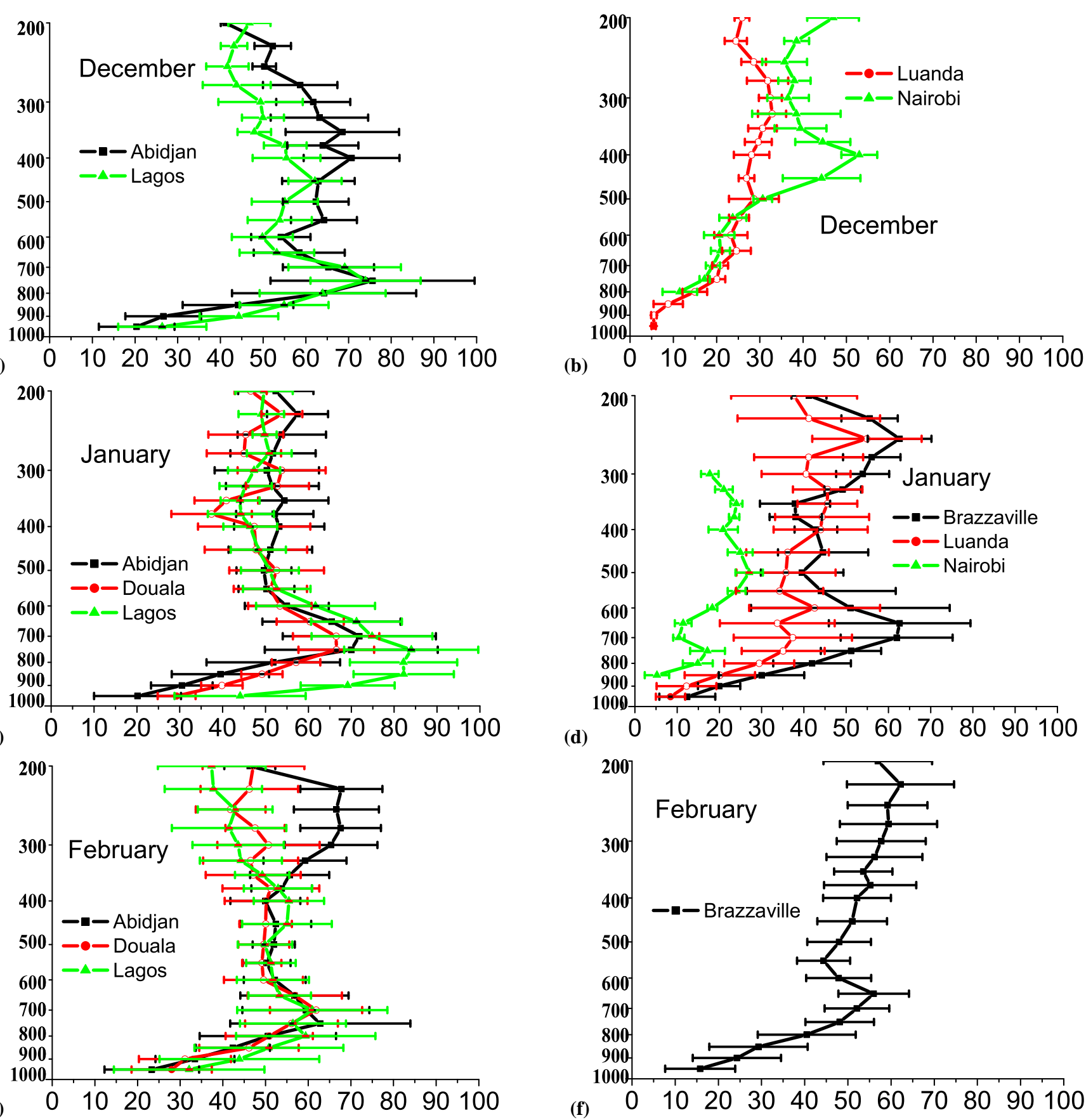

(d)
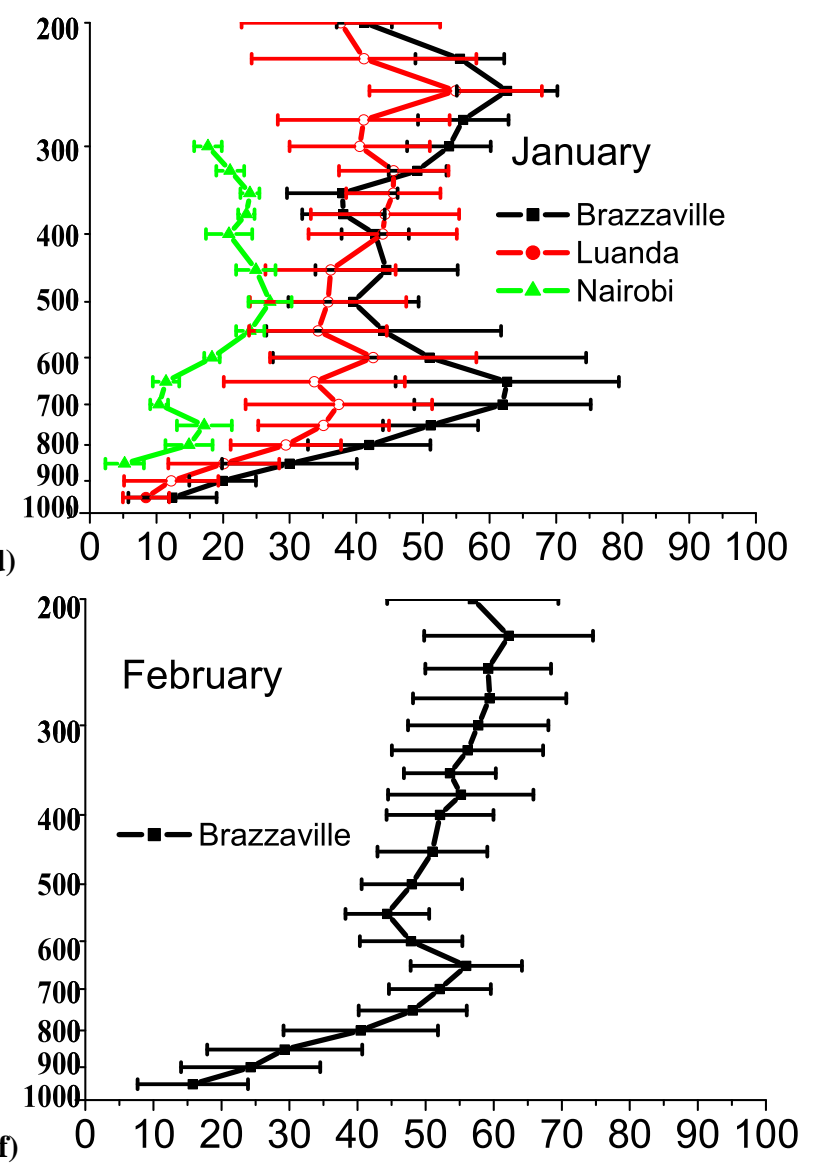

Fig. 5. Monthly mean ozone vertical profiles in parts per billion by volume (ppbv) as a function of pressure, over the different areas: for the Gulf of Guinea in December (a), January (c), February (e) with: Abidjan (black), Douala (red), Lagos (green); for Central and East Africa in December (b), January (d), February (f) with: Brazzaville (black), Luanda (red), Nairobi (green). The horizontal bars represent one standard deviation. 

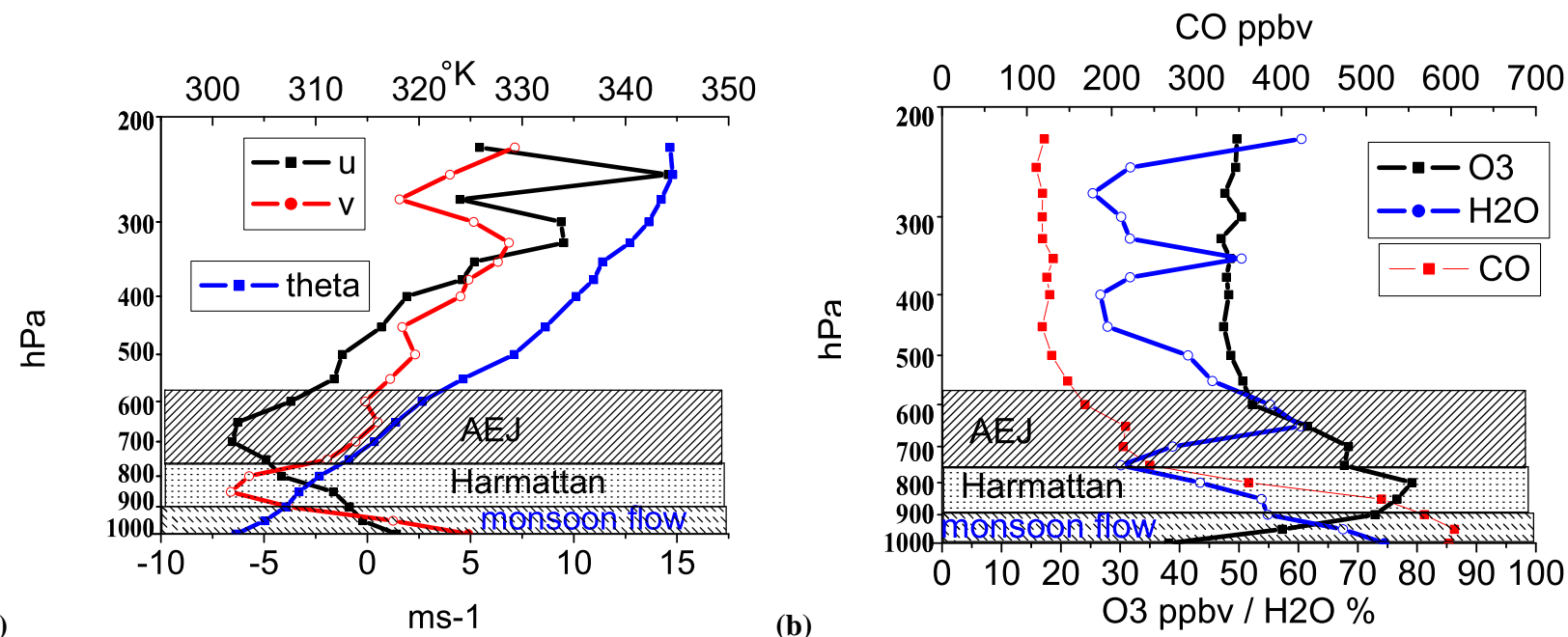

Fig. 6. Monthly mean vertical profiles over Lagos during January 2002 and 2003. Dynamical parameters (a). In red meridional components of the wind $v(\mathrm{~m} / \mathrm{s})$, in black: zonal components of the wind $u(\mathrm{~m} / \mathrm{s})$, in blue: potential temperature $(\mathrm{K})$, Chemical parameters $(\mathbf{b})$ : in red: $\mathrm{CO}$ (ppbv), black: $\mathrm{O}_{3}$ (ppbv), blue: $\mathrm{RH}(\%)$. The three different layers described in the text are highlighted in grey.

3 Distribution and variability of tropospheric ozone: seasonal and regional dependence. Monthly mean vertical profiles and seasonal cycles over Equatorial Africa

3.1 December-January-February (DJF): Biomass burning season in the northern tropics

As shown previously (Figs. 1a and 2e), biomass burning throughout the northern part of Equatorial Africa is at its maximum during the dry season and is an important source of ozone precursors (Hao et al., 1994). Figure 5 shows the ozone monthly mean vertical profiles during December, January, and February, over the Gulf of Guinea and over Central Africa plus Nairobi. For clarity reasons, Fig. 5 shows the ozone vertical profiles only over Nairobi. Other sites from East Africa are given in Fig. 19.

\subsubsection{Gulf of Guinea}

During the Northern Hemisphere dry season, hereafter named DJF, ozone concentrations maximize in the lower troposphere of the Gulf of Guinea. In this region, the highest concentrations reach 60 to $80 \mathrm{ppbv}$ with the overall maximum occurring in January over Lagos (Fig. 5c). The polluted layers are $150 \mathrm{hPa}$ to $300 \mathrm{hPa}$ thick, with a central pressure at $750-700 \mathrm{hPa}$. This enhancement is estimated to be about $+20-30$ ppbv over a background concentration level. In this study the term background has to be understood as the averaged concentration the profile would exhibit in case of no pollution. For example, a background profile for this season would be around $50 \mathrm{ppbv}$ throughout the troposphere. From the end of February the concentrations decrease.
For a complementary analysis, Fig. 6 shows the January monthly mean vertical profiles of the MOZAIC dynamical, thermal $(u, v, \theta$, Fig. $6 \mathrm{a})$, and chemical $\left(\mathrm{O}_{3}, \mathrm{RH}, \mathrm{CO}\right.$, Fig. 6b) parameters over Lagos. In order to take advantage of availability of the $\mathrm{CO}$ data these profiles have been computed from January 2002 and January 2003. The boundary layer is fed by maritime air masses embedded in the monsoon flow up to $900 \mathrm{hPa}$ and characterized by south-westerly winds, high relative humidity and low ozone (40-60 ppbv). High CO concentrations (500-600 ppbv) probably characterize local pollution. The monsoon flow is capped by the Harmattan layer (900-750 hPa) with north-easterly winds bringing ozone-rich ( $>65 \mathrm{ppbv}$ ), dry and stable air masses from a continental origin. The contribution of thermal winds associated with the meridional temperature gradient between the Gulf of Guinea and the continent, peaks into the AEJ $\left(7 \mathrm{~ms}^{-1}\right.$ for monthly-mean and up to $10-15 \mathrm{~ms}^{-1}$ on individual profiles between 750 and $550 \mathrm{hPa}$ ).

In order to explain the origin and formation of the observed enhanced ozone layers, Fig. 7a represents 3-D streamlines initialized in the ozone maximum at $850 \mathrm{hPa}$ over Lagos and traced backward for 5 days using the monthly mean wind fields of January 2002. Such trajectories show an origin from north-east in the lower troposphere $(820-900 \mathrm{hPa})$ over the eastern African region (Central African Republic, Sudan, Zaire, Uganda and Ethiopia), where biomass burning is active at this time of the year (Figs. 1a and 2e).

As explained before, in order to validate this methodology, we aim to quantify the robustness of such a connection. For that purpose we have compared the 3-D streamlines initialized in the ozone enhancement, at 850, 800 and $750 \mathrm{hPa}$ over Lagos and over Abidjan, with 5 days individual 
Table 3. Results of the statistical comparison between 3-D streamlines (from monthly mean analyses) and back-trajectories (from 6-hourly analyses) characteristic of DJF. For each region (Gulf of Guinea, Congo and Angola), $1.5^{\circ} \times 1.5^{\circ}$ square of air parcels (4×4 grid points centered around the airports) have been initialized, for one pressure level, for one month, and for one date. 5 days back-trajectories are computed every month for the 5 different dates (the 30th, 27th, 25th, 22nd and 20th). Numbers in brackets summarize the total of grid points initialized within each region for the four different years and the different pressure levels.

\begin{tabular}{|c|c|c|c|c|}
\hline \multicolumn{5}{|c|}{ January 2000, 2001, 2002 and 2003} \\
\hline Region of initialisation & Initialisation Pressure level & Selection criterion $S C$ & $\begin{array}{l}5 \text { days 3-D streamlines } \\
\text { [Total number of air parcels] }\end{array}$ & $\begin{array}{l}5 \text { days back-trajectories } \\
\text { [Total number of air parcels] }\end{array}$ \\
\hline Gulf of Guinea & $850-800-750 \mathrm{hPa}$ & $\begin{array}{c}S C l=\text { flow from the north-east } \\
\text { through northern regions of fires } \\
0^{\circ}-37^{\circ} \mathrm{E}-4^{\circ} \mathrm{N}-12^{\circ} \mathrm{N} \\
P \geq 700 \mathrm{hPa}\end{array}$ & $\begin{array}{l}90 \% \\
{[384]}\end{array}$ & $\begin{array}{c}88 \% \\
{[1280]}\end{array}$ \\
\hline Gulf of Guinea & 700-650-600 hPa & $\begin{array}{l}\qquad C 2=\text { flow from the east } \\
\text { through north-eastern regions of fires } \\
5^{\circ}-37^{\circ} \mathrm{E}-4^{\circ} \mathrm{N}-12^{\circ} \mathrm{N} \\
P \geq 600 \mathrm{hPa}\end{array}$ & $\begin{array}{c}97 \% \\
{[384]}\end{array}$ & $\begin{array}{c}78 \% \\
{[1280]}\end{array}$ \\
\hline Congo & $700-650 \mathrm{hPa}$ & $\begin{array}{c}S C 3=\text { flow from the north-east } \\
\text { through north-eastern regions of fires } \\
20^{\circ}-37^{\circ} \mathrm{E}-4^{\circ} \mathrm{N}-12^{\circ} \mathrm{N} \\
P \geq 650 \mathrm{hPa}\end{array}$ & $\begin{array}{l}91 \% \\
{[288]}\end{array}$ & $\begin{array}{c}81 \% \\
{[1152]}\end{array}$ \\
\hline Angola & $700-650 \mathrm{hPa}$ & $\begin{array}{l}S C 3=\text { flow from the north-east } \\
\text { through north-eastern regions of fires } \\
20^{\circ}-37^{\circ} \mathrm{E}-4^{\circ} \mathrm{N}-12^{\circ} \mathrm{N} \\
\quad P \geq 650 \mathrm{hPa}\end{array}$ & $\begin{array}{c}6 \% \\
{[288]}\end{array}$ & $\begin{array}{c}20 \% \\
{[1152]}\end{array}$ \\
\hline
\end{tabular}

back trajectories. Table 3 summarizes the statistical comparison. Selection criteria are the following: SC1 is satisfied when air parcels are connected to northern regions of fires $\left(0^{\circ}-37^{\circ} \mathrm{E}-4^{\circ} \mathrm{N}-12^{\circ} \mathrm{N}\right)$, staying below $700 \mathrm{hPa}$ along their north-easterly/south-westward pathway. SC2 is satisfied when air parcels are connected to north-eastern regions of fires $\left(5^{\circ}-37^{\circ} \mathrm{E}-4^{\circ} \mathrm{N}-12^{\circ} \mathrm{N}\right)$ along their easterly-westward pathway, staying below $600 \mathrm{hPa}$. The Harmattan allows a connection to be established between north-east regions of fires and Gulf of Guinea while AEJ allows connections to be established with eastern regions of fires. Both connections are robust with $90 \%$ and $97 \%$ of air parcels satisfying SC1 and $S C 2$ respectively. They are confirmed with individual back-trajectories ( $88 \%$ and $78 \%$ respectively).

For each case, the comparison shows negligible differences in the interpretation of the origin of air parcels. An example of such a comparison for two pressure levels, one year, and one date of initialization for individual back-trajectories is shown in Fig. 7. As said previously the choice of the year 2002 for the 3-D streamlines is function of the sampling frequency over the city in the MOZAIC database. Figure $7 b$ shows back trajectories initialized on the 30 January 2002, at $850 \mathrm{hPa}$ over Lagos. Figure 7d gives back trajectories initialized on the 30 January 2002, at $650 \mathrm{hPa}$, while Figs. 7a and c give the 3-D streamlines for the same altitudes respectively. Individual trajectories show the same north-easterly origin (characteristic of the Harmattan) as the 3-D streamlines ini- tialized at $850 \mathrm{hPa}$ in January 2002 and the same easterly origin (characteristic of the AEJ) at $650 \mathrm{hPa}$. The main difference concerns the transport speed. Back-trajectories initialized at $850 \mathrm{hPa}$ visit regions situated a little bit further north. This is obviously due to the stationary state represented with the 3-D streamlines, for which monthly analyses represent smoothed winds fields. This smoothing also prevents 3-D streamlines representing dynamical features with short variability (few days), such as easterly waves. But the goal of this study is to establish the connections between regions of fire and ozone enhancements.

Within the AEJ layer, ozone concentrations decrease with altitude (65 to $50 \mathrm{ppbv}$ ). Note that very similar vertical structures are measured over the three sites of the region (Douala, Lagos and Abidjan). What could be the processes responsible of the absence of any strong zonal gradient along the AEJ over the Gulf of Guinea coast? The AEJ lies just on the southern edge of the regions of fires (Figs. 7c and d) over a large longitudinal band and may be constantly sustained with ozone and/or ozone precursors by winds from north-east, with ascending motion, so that one could expect to observe an ozone zonal gradient in it. Note that both trajectories and 3-D streamlines flowing from the east originally come from the low levels $(\mathrm{P}>800 \mathrm{hPa})$, with $28 \%$ and $21.5 \%$ respectively, due to synoptic upward motion below the AEJ. The absence of zonal gradient suggests that after ozone is initially formed at regional scale in the Harmattan layer by 


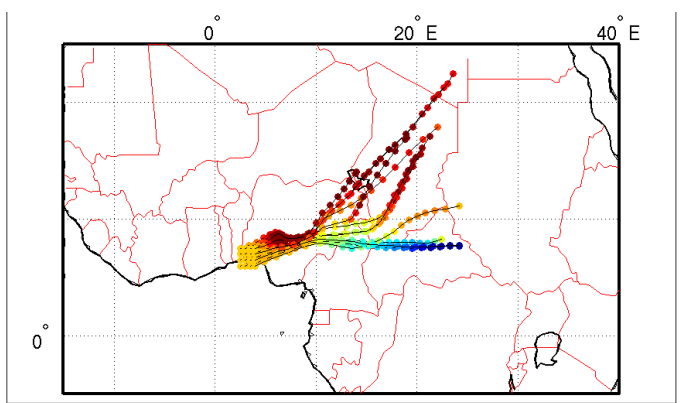

(a) 650
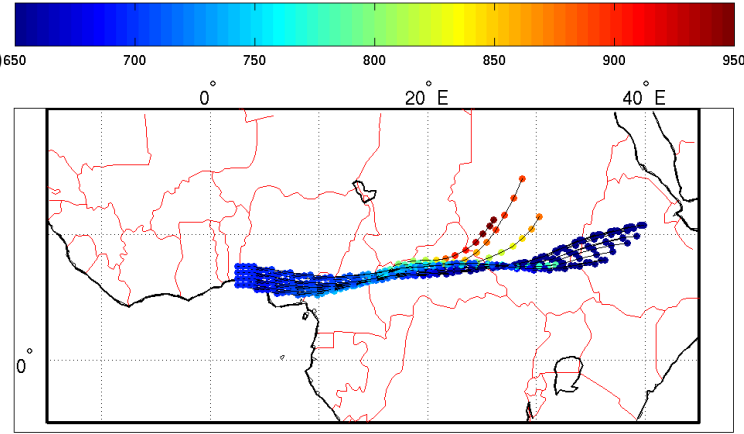

(c) 600

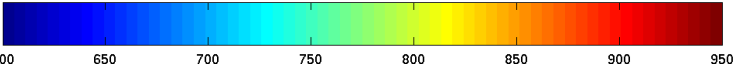

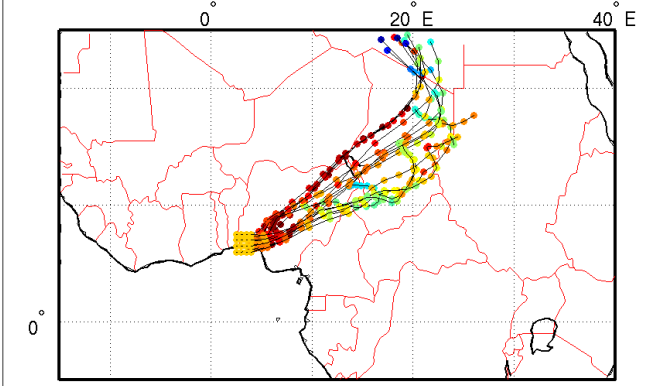

(b) 650
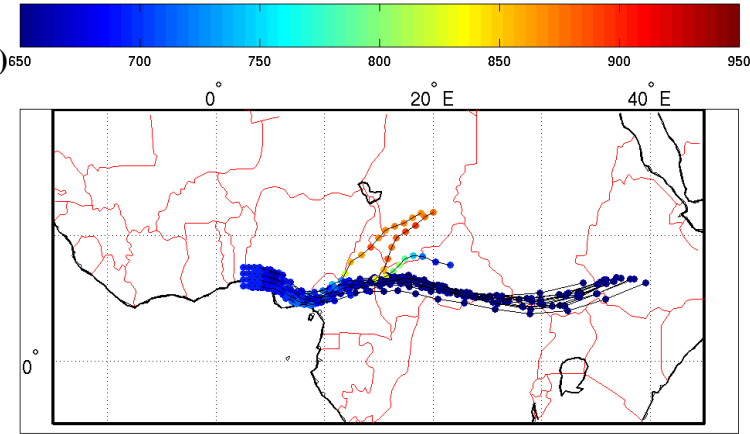

(d) 600

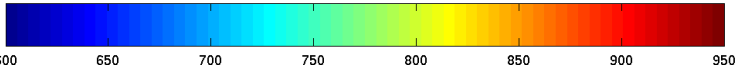

Fig. 7. 5 days 3-D streamlines (left panels) and individual back-trajectories (right panels) computed with monthly and daily ECMWF analyses respectively, and initialized over: Lagos in January 2002 at $850 \mathrm{hPa}$ (a), and the 30th of January 2002 at $850 \mathrm{hPa}$ (b). Lagos in January 2002 at $650 \mathrm{hPa}(\mathbf{c})$, and the 30th of January 2002 at $650 \mathrm{hPa}(\mathbf{d})$. Trajectories are colour-coded with pressure (hPa), from $650 \mathrm{hPa}$ to $950 \mathrm{hPa}(\mathrm{a}$ and b); and from $600 \mathrm{hPa}$ to $950 \mathrm{hPa}$ (c and d).

rapid photochemical processes over the band of fires (Jonquieres et al., 1998; Singh et al., 1996), the slower photochemical enhancements of ozone during the transport along the AEJ is either weak or balanced by mixing processes; otherwise the zonal gradient of ozone should be stronger. A Lagrangian aircraft campaign and model studies would be needed to investigate whether the dominant process creating the dry-season ozone maximum can be attributed to rapid and regional photochemistry or to slower and continental-scale photochemistry. This is beyond the scope of this study.

The stability of the Harmattan layers combined with the subsidence caused by the Saharan Anticyclone (found near $500 \mathrm{hPa}$ between $5^{\circ}-15^{\circ} \mathrm{N}$, a feature which is present between November and February) restricts ascending motions. This prevents any efficient vertical transport towards the middle and upper troposphere (from $500 \mathrm{hPa}$ to $200 \mathrm{hPa}$ ) where ozone concentrations remains constant over the Gulf of Guinea, with about $50 \mathrm{ppbv}$ up to $200 \mathrm{hPa}$. An exception is seen in February over Abidjan, near $250 \mathrm{hPa}$, with 70 ppbv. The origin could be lightning activity, or detrainment from ITCZ (situated just southward) of air masses pre- viously loaded with pollution from northern biomass burning emissions, as noticed by Edwards et al. (2003).

\subsubsection{Central and East Africa}

In the two other regions situated further south (Central and East Africa), only Brazzaville shows such an ozone enhancement in the lower troposphere, near $650 \mathrm{hPa}$, within a layer $200 \mathrm{hPa}$ thick, with concentrations from 50 to $65 \mathrm{ppbv}$ (Figs. 5d and f). Luanda and Nairobi exhibit lower concentrations, never exceeding 20-40 ppbv on average. Such enriched ozone layers over Brazzaville during the boreal dry season have been already observed during the TRACEA campaign and attributed to fires in the northern regions (Nganga et al., 1996). The upper troposphere over Brazzaville, near $200 \mathrm{hPa}$, also presents high concentrations with more than $60 \mathrm{ppbv}$ (Figs. 5d and 5f).

Figure 8a shows that the 3-D streamlines ending in the ozone maximum in the lower troposphere over Brazzaville have a northeasterly origin (over the Sudan) from the northern boreal hemisphere where biomass fires are active. The connection between north-east fires and lower troposphere 

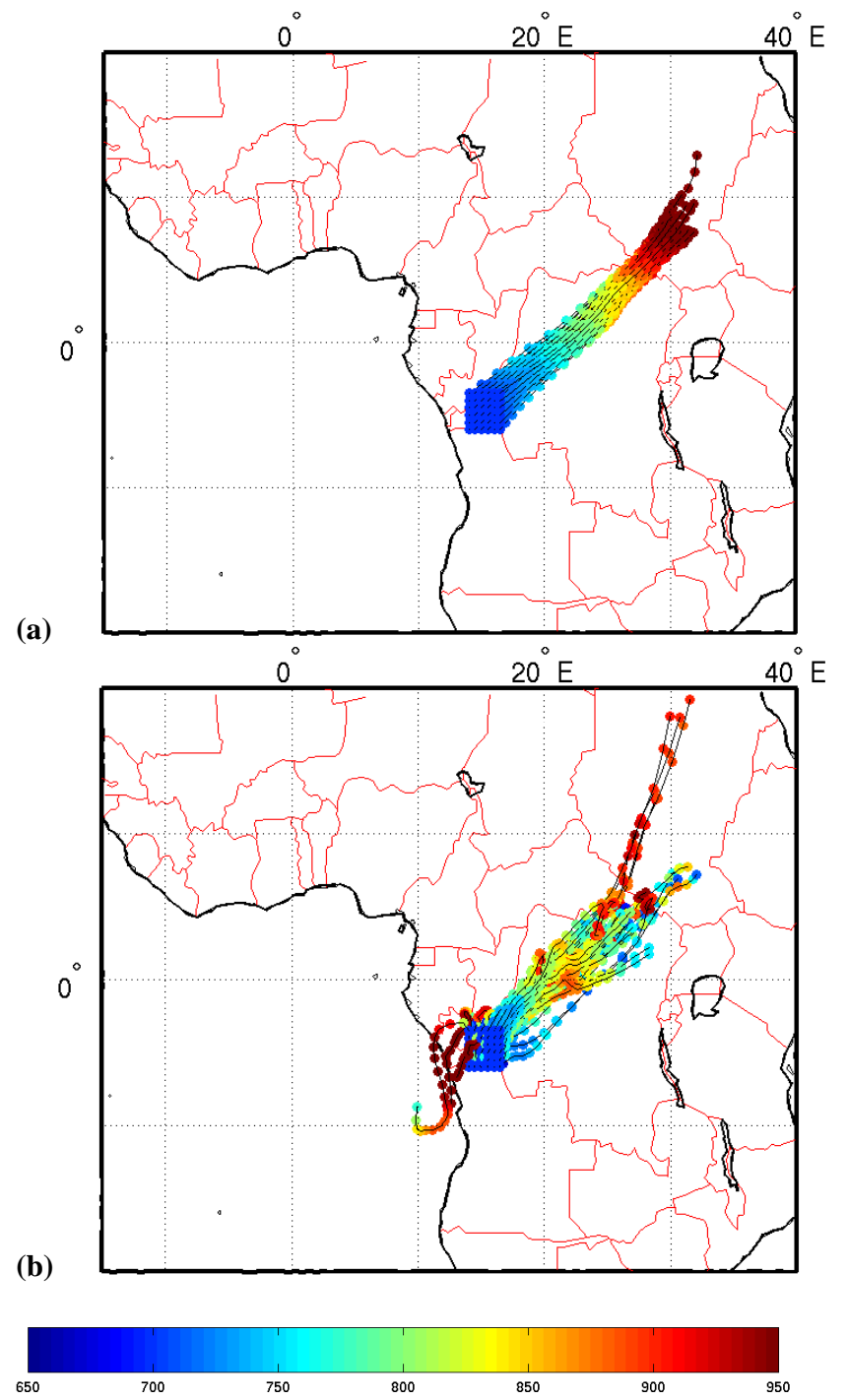

Fig. 8. 5 days 3-D streamlines (a) and individual back-trajectories (b) computed with monthly and daily ECMWF analyses respectively, and initialized over Brazzaville in January 2002 at $700 \mathrm{hPa}$, and the 30th of January 2002 at $700 \mathrm{hPa}$. Trajectories are colourcoded with pressure (hPa), from $650 \mathrm{hPa}$ to $950 \mathrm{hPa}(\mathrm{a}$ and b).

of Brazzaville and Luanda is robust with $91 \%$ of air parcels satisfying the selection criterion (SC3, Table 3), and is confirmed with individual back-trajectories (81\%) (see Fig. 8b). However, the latter also show a possible monsoon flow influence (around $7 \%$ over the 4 years). Such a transport by north-easterlies emanating from the semi-permanent Saharan High affects both the Gulf of Guinea and Central Equatorial Africa when the ITCZ peaks is in its southernmost position (see Fig. 2e). This explains the similar shapes of the vertical profiles over Lagos and Brazzaville during DJF (Fig. 9). However, note that the ozone maximum over Brazzaville is shifted vertically compared to the one over Lagos. This reflects the higher altitude of the trade wind inversion at

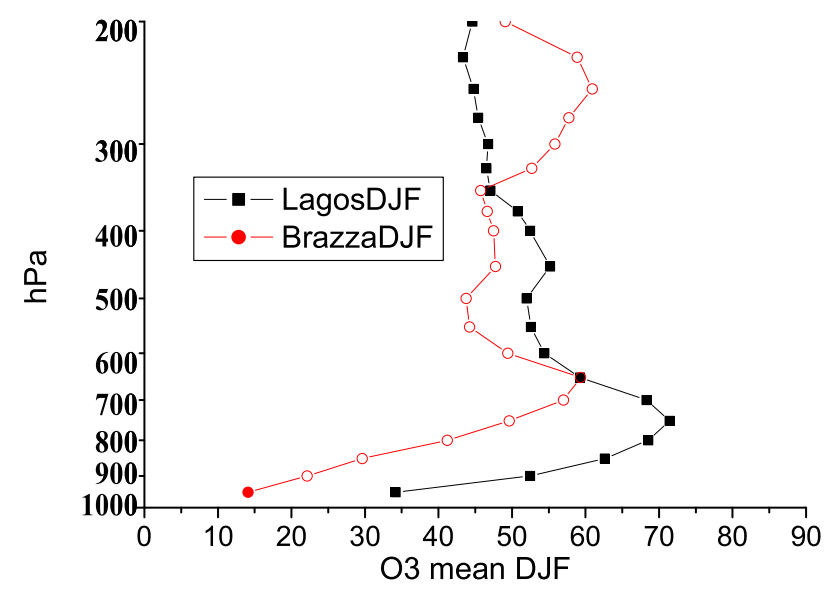

Fig. 9. Seasonal ozone vertical profiles over Lagos (black) and Brazzaville (red) in DJF (biomass burning season in the northern tropics).

the vicinity of the convergence zone. Further south, this feature is absent from the January and February vertical profiles over Luanda where ozone concentrations are quite low. The absence of such enhanced layers is explained by the lack of north-easterly influence as seen in the ECWMF wind fields (see Fig. 2e): Most of the time Luanda is on the southern side of the ITCZ. Both back-trajectories and 3-D streamlines show a monsoon flow influence, with more than $80 \%$ of this origin. The SC3 north-easterly influence occurs only $20 \%$ of the time with individual back-trajectories, and only $6 \%$ with 3-D streamlines (Table 3).

Concerning the strong ozone enhanced layer appearing in January and February over Brazzaville near 300-200 hPa, back trajectories show a possible north-easterly influence originating from the lower levels over regions of fires (figure not shown). Indeed, Chatfield et al. (2004) have observed such an influence from Sahel fires in the upper troposphere over Ascencion Island (14 South). Besides, according to Jenkins and Ryu (2004a and 2004b) there is a possible influence of lightning which is maximum in the opposite hemisphere of the biomass burning activity. Using MOPITT and GOME data, Edwards et al. (2003) have shown that atmospheric layers observed in the middle troposphere of the southern hemisphere and coming from the lower troposphere over Sahel, could be exposed to lightning shortly after have been loaded by biomass burning emissions. Indeed polluted air masses from North-East fires regions could be entrained into the ITCZ which is situated between fires regions and Brazzaville at this time of the year. Consequent $\mathrm{NO}_{\mathrm{x}}$ and $\mathrm{CO}$ could then be combined to explain such an enhancement. 


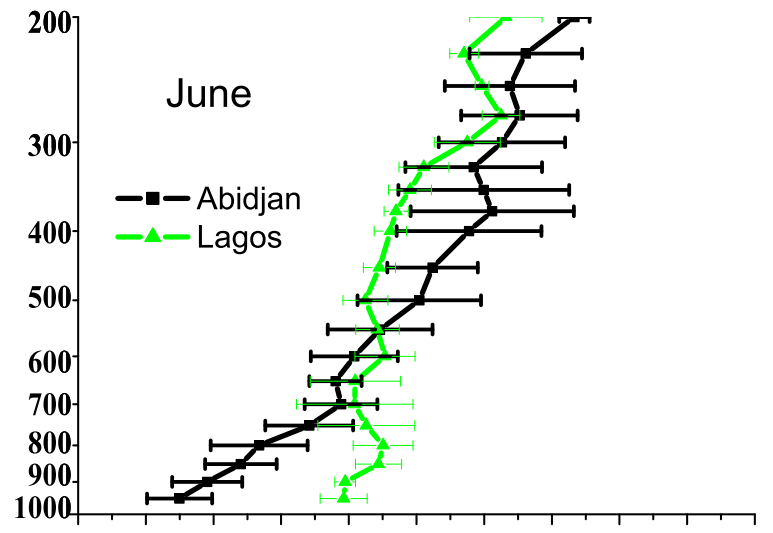

(a)
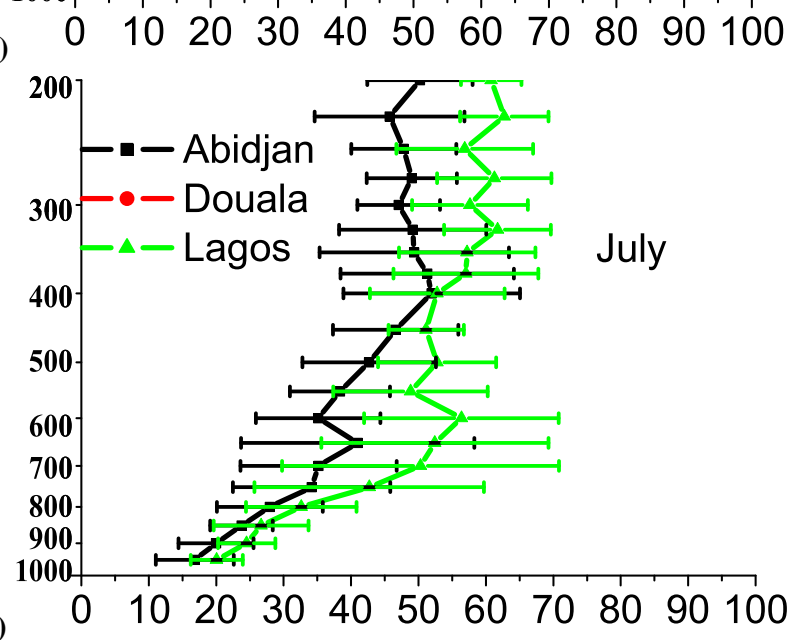

(b)

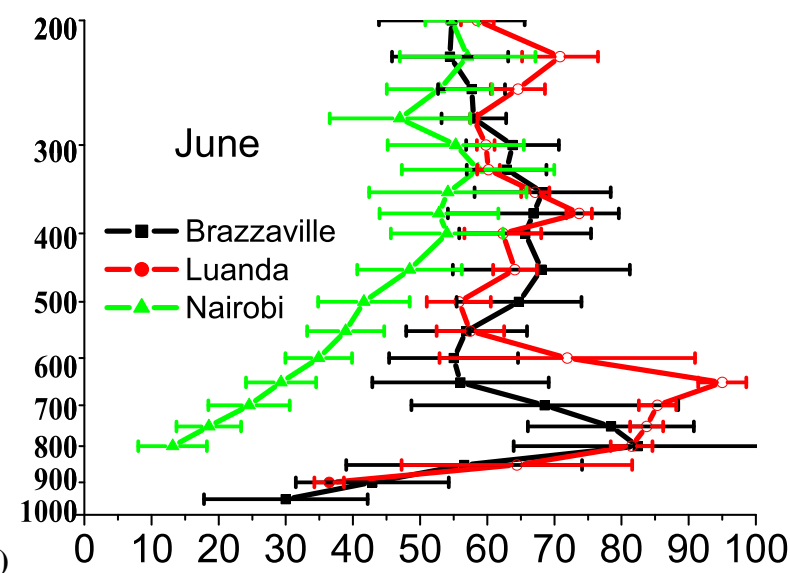

(c)

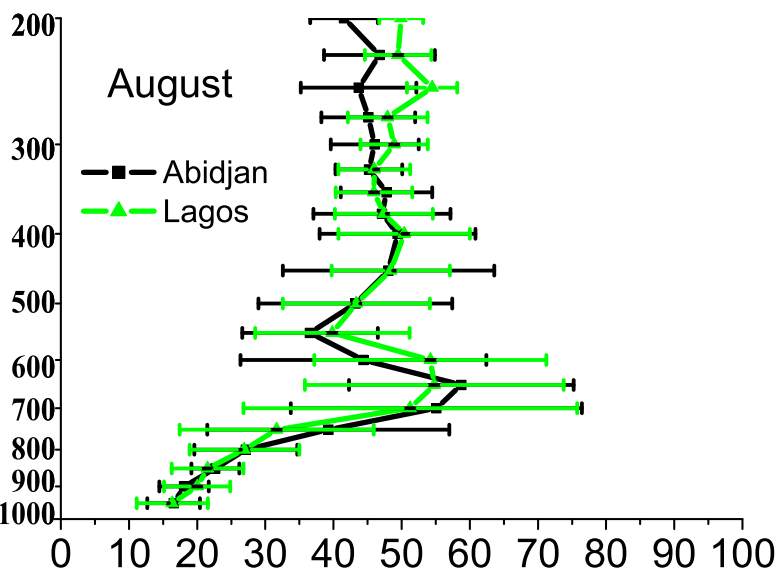

(d)
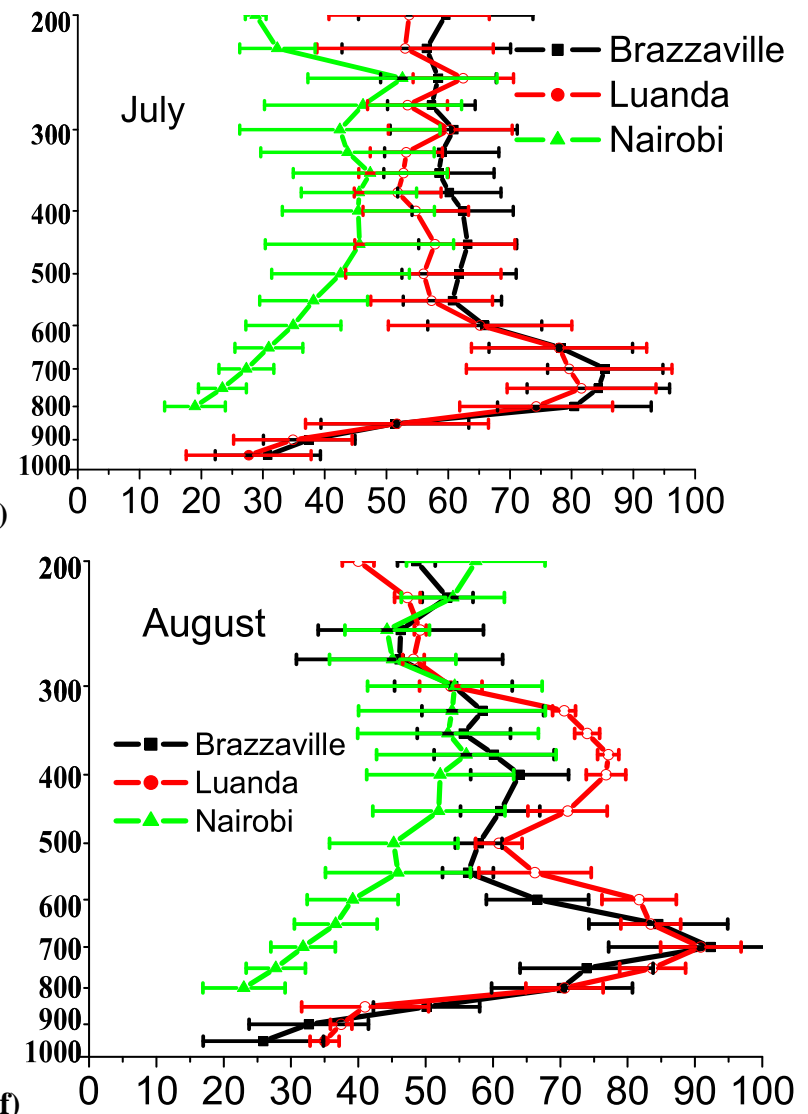

Fig. 10. Monthly mean ozone vertical profiles in parts per billion by volume (ppbv) as a function of pressure, over the different areas: for the Gulf of Guinea in June (a), July (c), August (e) with: Abidjan (black), Douala (red), Lagos (green); for the Central and East Africa in June (b), July (d), August (f) with: Brazzaville (black), Luanda (red), Nairobi (green). The horizontal bars represent one standard deviation about mean.

3.2 June-July-August (JJA) season : Biomass burning season in the southern tropics

Figure 10 shows the monthly mean ozone vertical profiles over Central and East Africa (right column), and over the Gulf of Guinea (left column) for the whole period of mea- surements, for June (Figs. 10a and b), July (Figs. 10c and d), and August (Figs. 10e and f). 


\subsubsection{Central and East Africa}

During the southern hemisphere dry season, there is an ozone enhancement in the lower troposphere over both Brazzaville and Luanda, between 900 and $600 \mathrm{hPa}$ (Fig. 10). The concentrations maximize at $700 \mathrm{hPa}$ with $90 \mathrm{ppbv}$ on average. In contrast, Nairobi presents the lowermost concentrations in these lower levels, with only 20 to 40 ppbv, although higher than during DJF.

In Fig. 11, the 3-D streamlines clearly demonstrate that air masses in the lower troposphere travel south-easterly from west of Lake Malawi. This is a region of intense fire activity (Figs. $1 \mathrm{~b}$ and 2f), with ozone precursors probably being injected into the continental south-easterlies as they pass over the fires of the Democratic Republic of Congo, Zambia and Zimbabwe before moving up to Brazzaville and Luanda. This connection is robust with both the 3-D streamlines and the individual back-trajectories with more than $86 \%$ and $81 \%$ respectively, calculated over 2000, 2001, 2002 and 2003 (Table 4). It confirms findings by Garstang et al. (1996) during the TRACE-A campaign about the anticyclonic circulation over the subcontinent during the winter half-year that reaches a $80 \%$ daily occurrence in July, allowing a circulation from the east on the northern edge of the high. The MOZAIC dynamical parameters also confirm this connection (Fig. 12), with strong negative zonal wind, $u=-10 \mathrm{~m} . \mathrm{s}^{-1} ; v=+5 \mathrm{~m} . \mathrm{s}^{-1}$. As observed in DJF over the Gulf of Guinea, ozone enhanced layers due to biomass burning products are particularly stable. Indeed, during the TRACE-A campaign, $5 \mathrm{~km}$ stable layers have been observed, due to strong subsidence-induced inversion, inhibiting vertical transport of pollution (Chatfield et al., 1996 and Fuelberg et al., 1996). In the lower troposphere (up to $900-850 \mathrm{hPa}$ ) Congo and Angola are subject during the entire year to the southern monsoon flux, characterized by positive zonal and meridional winds (Fig. 12) of up to $3-4 \mathrm{~m} . \mathrm{s}^{-1}$ on the monthly mean basis, and relative humidity higher than $90 \%$. That explains the strong ozone vertical gradient in the lower layers of the troposphere (see Fig. 12a).

At this stage of the analysis, it is interesting to compare the dry seasons of Angola-Congo (in JJA) and Gulf of Guinea (in DJF). Figure 12 shows that they present the same shape in the lower troposphere, but with ozone concentrations over Brazzaville being $15 \%$ higher within a thicker layer $(250 \mathrm{hPa}$ against $150 \mathrm{hPa}$ over Abidjan). Given that the magnitude of burning in northern and southern African tropical belts is very similar (48\% of the African fires are in the north and $52 \%$ in the south, according to Hao and Liu, 1994), the difference in the ozone concentrations may partly reflect the different types of vegetation found in the African northern and southern hemispheres. Figure 3 shows that in the southern hemisphere deciduous forest-woodland savanna predominates whereas brush-grass savannas become important in the north. According to Duncan et al. (2003) emission factors of pollutant fires from tropical forest are higher for CO (104 g
$\mathrm{CO} / \mathrm{kg} \mathrm{DM})$, than fires from savannas $(65 \mathrm{~g} \mathrm{CO} / \mathrm{kg} \mathrm{DM})$. It seems reasonable to simply argue that higher $\mathrm{CO}$ concentrations in the southern regions may contribute to higher ozone concentrations (assuming that $\mathrm{NO}_{\mathrm{x}}$ emissions are also higher in the south).

Even if the East Africa region does not present ozone enhanced layers in the lower troposphere, concentrations are higher than during the DJF season. There is an obvious influence of the local biomass burning, occurring over Rwanda, Tanzania, Mozambique, Zimbabwe and Kenya in JJA, along the south-eastern coast of Africa. Figure 14 shows the MOZAIC dynamical parameters recorded over Kigali with stable (strong $\theta$ gradient) flow from south east $\left(v=2.5 \mathrm{~m} . \mathrm{s}^{-1}\right.$, $\left.u=-2.5 \mathrm{~m} \cdot \mathrm{s}^{-1}\right)$, characterized by high RH $(80 \%)$. This flow originates from the south-eastern Africa in the confluence area of the Mascarene anticyclone and the east African low level jet, passes over the regions of fires where it may be loaded with ozone precursors, and then passes up to Kigali.

In the middle troposphere, above $600 \mathrm{hPa}$, Central Africa and East Africa present higher concentrations than in DJF, with 60 ppbv ozone over Brazzaville and Luanda (Fig. 10). Above $400 \mathrm{hPa}$, Nairobi presents similar concentrations at around $50 \mathrm{ppbv}$.

The two regions are under complex influences, involving variations in trans-central-African flow, especially during the end of this season (August) and during austral spring (SON). Both South America and Asia can influence these regions through upper troposphere circulation (Krishnamurti et al., 1996; Jacob et al., 1996). The tropospheric ozone columns from TOMS suggest a strong inflow from Indian Ocean, which may have high ozone contents (Krishnamurti et al., 1996; Chatfield et al., 2004). As noticed by Thompson et al. (2003b), this origin confined between $40^{\circ}-70^{\circ} \mathrm{E}$, over the Indian Ocean, corresponds to a region that may be influenced by pollution from nearby East African regions of fires, or India (Lelieveld et al., 2001).

\subsubsection{Gulf of Guinea}

From June to August (JJA, Fig. 10), the lower troposphere exhibits much lower ozone concentrations than during the dry season. Ozone concentrations from 20 to $30 \mathrm{ppbv}$ have been measured over Lagos and Abidjan from the ground up to $780 \mathrm{hPa}$. The monsoon event with clean oceanic flow from south-west is particularly active over this region, from the ground up to $800 \mathrm{hPa}$ with RH around $90 \%$ on average (figure not shown).

Above this ozone-depleted layer, an ozone enhancement is measured over Lagos in July, from 700 to $600 \mathrm{hPa}$, with 45 ppbv ozone (Fig. 10c). A similar behaviour is observed over Lagos and Abidjan in August with an enhanced ozone (55 ppbv) layer between 750 and $600 \mathrm{hPa}$ (Fig. 10e).

The 3-D streamlines ending within these ozone enhancements do not exhibit a dominant transport process as robust on a monthly basis as those observed during the northern 

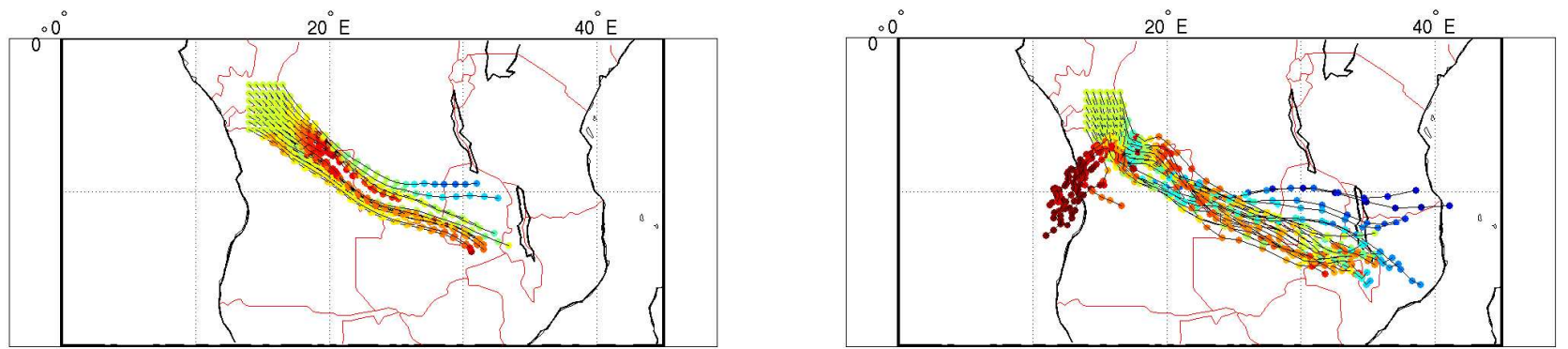

(a)

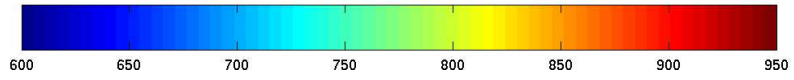

(b)

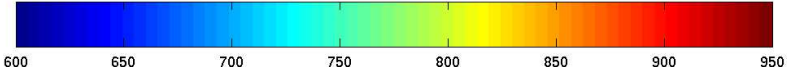

Fig. 11. 5 days 3-D streamlines (a) and individual back-trajectories (b) computed with monthly and daily ECMWF analyses respectively, and initialized over: Brazzaville in July 2003 at $800 \mathrm{hPa}$ (a), and the 30th of July 2003 at $800 \mathrm{hPa}$ (b). Trajectories are colour-coded with pressure $(\mathrm{hPa})$, from $600 \mathrm{hPa}$ to $950 \mathrm{hPa}$.

(a)

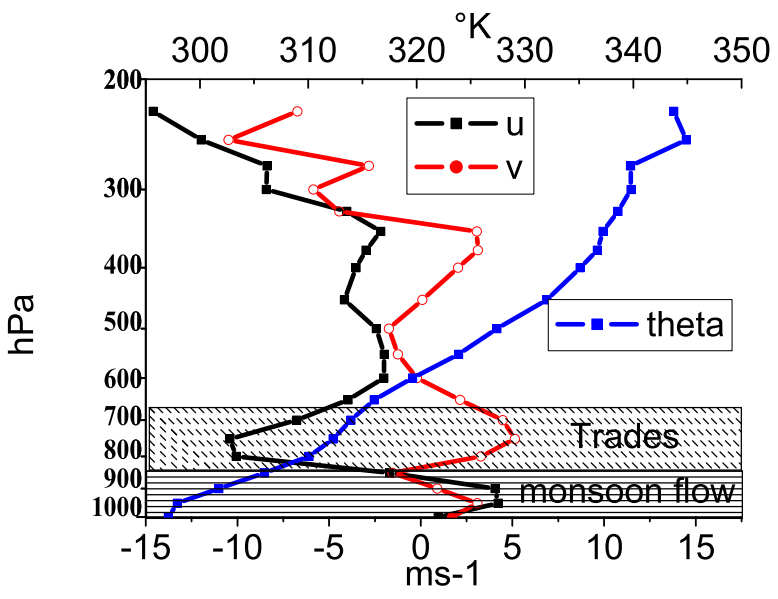

(b)

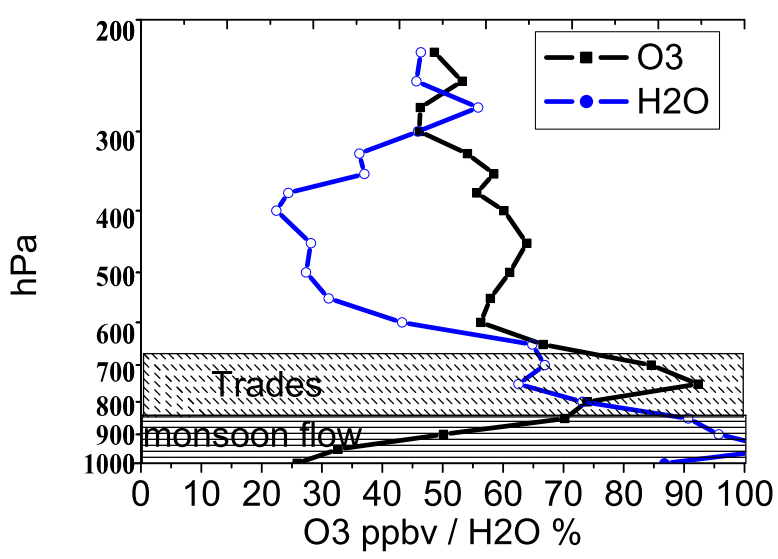

Fig. 12. Monthly mean vertical profiles of ozone over Brazzaville during August. Dynamical parameters (a): in red: $v$ (m/s), black: $u$ (m/s), blue: potential temperature (K); Chemical parameters (b): in black: $\mathrm{O}_{3}(\mathrm{ppbv})$, in blue: $\mathrm{RH}(\%)$. Trades layer is in grey.

hemispheric dry season cases. Connections between fires occurrence over southern regions and these layers are not robust on a monthly basis, with only $15.6 \%$ of back-trajectories and only $7.5 \%$ of 3-D streamlines coming from fires over austral Africa to the Gulf of Guinea (see Table 4). Indeed ozone enhancements themselves are not a systematic feature within this season as characterized by strong standard deviations. During JJA, the Gulf of Guinea can present two different shapes of profile: with or without ozone enhanced layers around $650 \mathrm{hPa}$. Figure 15a represents the seasonal JJA ozone distribution over Lagos (black) and Abidjan (red) only when such enriched ozone layers appear in individual profiles. The daily trajectories initialized for such a case in the $700-600 \mathrm{hPa}$ ozone enhanced layers reveal a south-easterly origin from Southern Hemisphere region of fires (Congo Democratic Republic, see 5 days back-trajectories, Fig. 15c).
The monsoon flow from the south west is also seen, but do not contribute to the transport of polluted air. Figure $15 \mathrm{~b}$ shows the seasonal ozone distribution without any ozone enhancements over Lagos and Abidjan. One example of the associated connection is then represented by the individual back-trajectories, between the 29 and 24 July 2000 . They show a north-easterly influence originating from Saharan regions (Fig. 15d). Such an example shows the limitation of monthly analyses to explain all the possible connections. However, we can still conclude that south-easterlies are responsible for enhanced layers measured in the Gulf of Guinea. Indeed, depending on the position of the ITCZ, south or north of Lagos and Abidjan, south-easterlies from fires regions are, or are not the prominent feature over the Gulf of Guinea. Moreover, this process may explain why the shapes of the vertical profiles are similar between north and 
Table 4. Same as Table 3 for JJA. Selection criterion has been defined: SCl=air parcels with a flow from southeast that passes over regions of fires and stay below $600 \mathrm{hPa}$; Results are given as $\%$ of the total of air parcels.

\begin{tabular}{|c|c|c|c|c|}
\hline \multicolumn{5}{|c|}{ July 2000, 2001, 2002 and 2003} \\
\hline Region of initialisation & Initialisation Pressure level & Selection criterion $S C$ & $\begin{array}{c}5 \text { days 3-D streamlines } \\
\text { [Total number of air parcels] }\end{array}$ & $\begin{array}{l}5 \text { days back-trajectories } \\
\text { [Total number of air parcels] }\end{array}$ \\
\hline Gulf of Guinea & $700-650-600 \mathrm{hPa}$ & $\begin{array}{c}S C l=\text { flow from the south-east } \\
\text { through southern regions of fires } \\
13^{\circ}-37^{\circ} \mathrm{E}-5^{\circ} \mathrm{S}-25^{\circ} \mathrm{S} \\
P \geq 600 \mathrm{hPa}\end{array}$ & $\begin{array}{l}7.5 \% \\
{[384]}\end{array}$ & $\begin{array}{l}15.6 \% \\
{[1280]}\end{array}$ \\
\hline Congo and Angola & $800-750-700 \mathrm{hPa}$ & $\begin{array}{c}S C l=\text { flow from the south-east } \\
\text { through southern regions of fires } \\
13^{\circ}-37^{\circ} \mathrm{E}-5^{\circ} \mathrm{S}-25^{\circ} \mathrm{S} \\
P \geq 600 \mathrm{hPa}\end{array}$ & $\begin{array}{l}86 \% \\
{[288]}\end{array}$ & $\begin{array}{c}81 \% \\
{[1152]}\end{array}$ \\
\hline
\end{tabular}

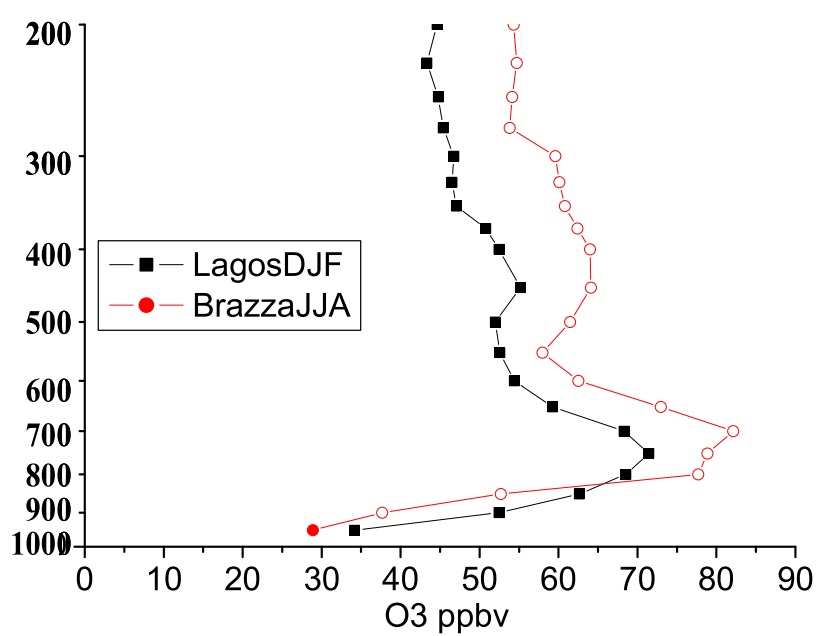

Fig. 13. Seasonal ozone vertical profiles over Lagos (black) and Brazzaville (red) during their respective biomass burning season DJF and JJA.

south (Fig. 16), with higher ozone concentrations ( $85 \mathrm{ppbv}$ over Brazzaville, 70 ppbv over Lagos) measured in the southern hemisphere at the same time, and shifted vertically over the Gulf of Guinea. The decrease in the ozone concentrations $(-15 \mathrm{ppbv})$ during transport may be attributed to convective and turbulent mixing processes. As cross-equatorial advection is very slow with a wind speed around $2 \mathrm{~m} . \mathrm{s}^{-1}$, most of the time, individual cases have shown that more than 8 days are necessary to transport air masses from the regions of fires to Gulf of Guinea. Regional transport explains the similarities in the vertical profiles. South-easterlies emanating from the SASTA anticyclone situated over Angola reach the Gulf of Guinea coast, as the ITCZ peaks in its northern position $\left(10-15^{\circ} \mathrm{N}\right)$ at this time of the year. The vertical displacement of the ozone enhanced layers between the two profiles is associated with an increase in altitude of the trade wind inversion level downstream of the anticyclone.
The middle and upper troposphere show ozone concentrations from 45 to $65 \mathrm{ppbv}$ (Figs. 15a and b). The middle troposphere shows higher concentrations than the lower troposphere, as a consequence of the ozone-poor maritime boundary layer origin air of the monsoon flow below 600$700 \mathrm{hPa}$. Between $300 \mathrm{hPa}$ and $200 \mathrm{hPa}$, Lagos shows higher concentrations than during the dry season, with a $+15 \mathrm{ppbv}$ difference (compared to Fig. 5c). As described by Thompson et al. (2003b) a possible entrainment of air across the ITCZ could explain this difference as biomass burning is occurring in the Southern Hemisphere at this time of year. Moreover, lightning $\mathrm{NO}_{\mathrm{x}}$ or local pollution uplifted in convective regions may be responsible for such ozone enhancements.

\subsection{March-April-May and September-October-November [MAM and SON], the intermediate seasons}

Figures 17 and 18 represent the monthly mean vertical profiles of ozone during intermediate seasons, March-April-May (Fig. 17), and September-October-November (Fig. 18); over the Gulf of Guinea (left column) and over Central Africa and Nairobi (right column). Finally, as a summary of this climatology, Fig. 19 gives the annual overview through the seasonal cycles for three layers $100 \mathrm{hPa}$ thick, centered on $750 \mathrm{hPa}$ (Fig. 19e and f), $500 \mathrm{hPa}$ (Fig. 19c and d) and $250 \mathrm{hPa}$ (Fig. 19a and b).

\subsubsection{Gulf of Guinea}

During the transition seasons, boreal spring (MAM) and fall (SON), ozone concentrations are weaker in the lower levels of the troposphere (Fig. 17a and Fig. 18a). This clearly confirms the importance of the biomass burning in the African northern tropics for ozone production. As the northern Hemispheric biomass burning seasons starts during November and stops during March, some ozone enhancements in the lower troposphere are seen over Abidjan in March (up to $60 \mathrm{ppbv}$, Fig. 17a), and over Lagos and Douala in November (up to 


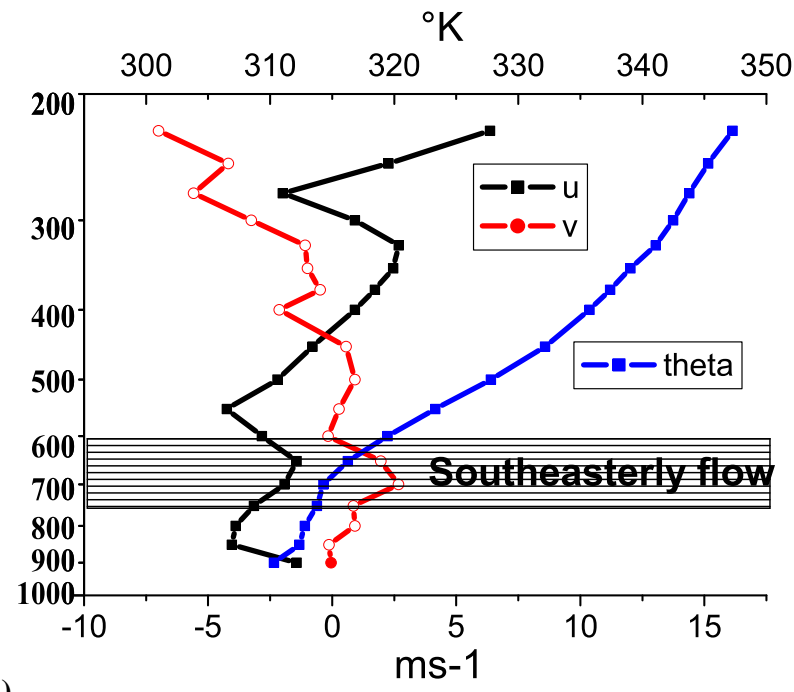

(a)

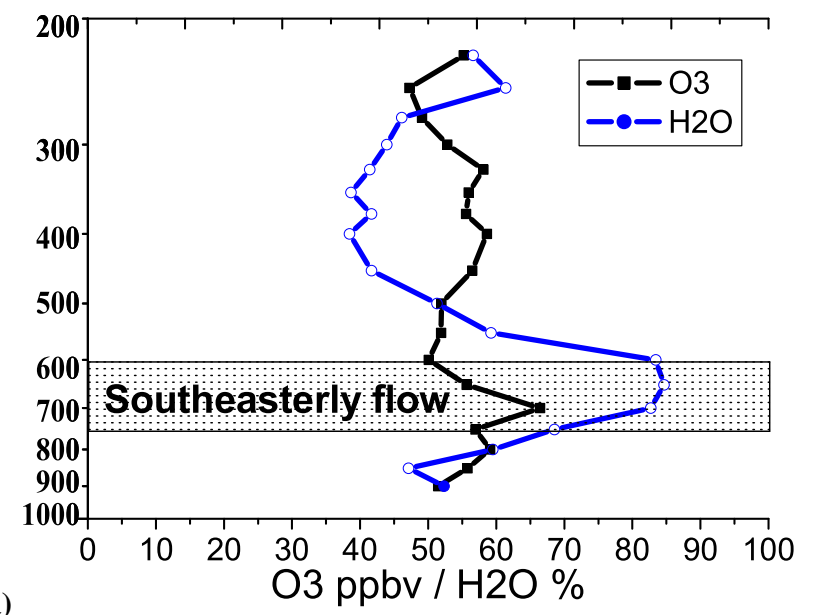

Fig. 14. Monthly mean vertical profiles over Kigali during August. Dynamical parameters (a): in red: $v$ (m/s), black: $u$ (m/s), blue: potential temperature (K); Chemical parameters (b) in black: $\mathrm{O}_{3}$ (ppbv), blue: $\mathrm{RH}(\%)$.

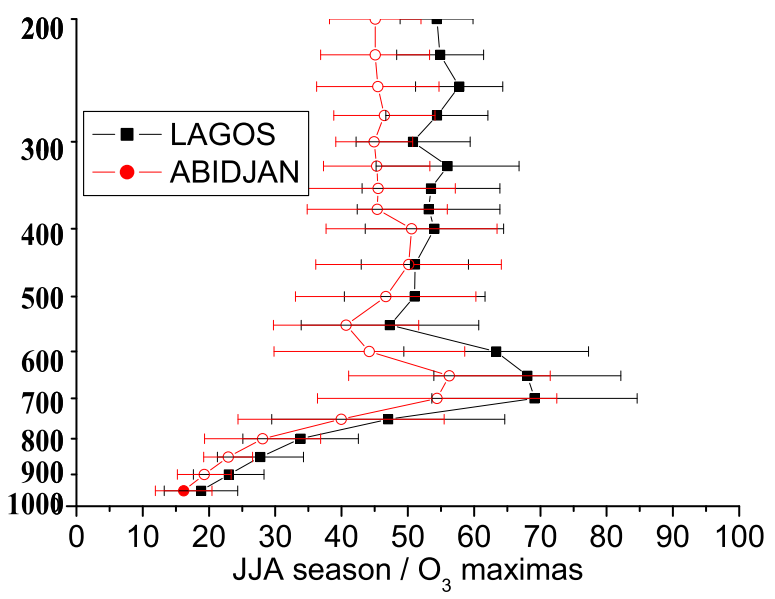

(a)

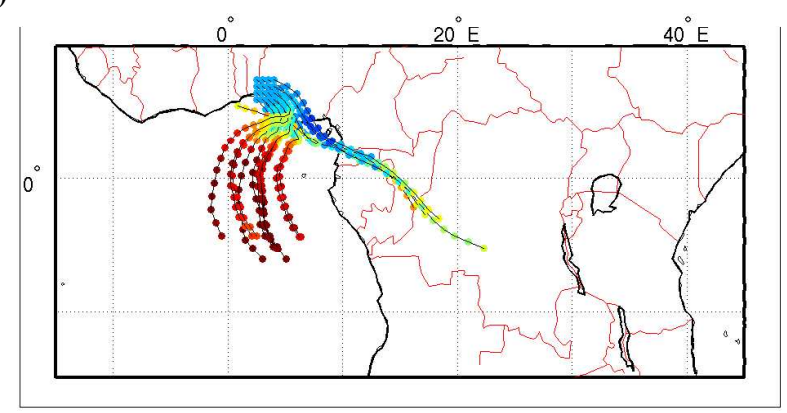

(c) 600

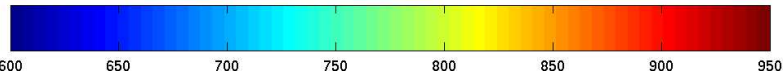

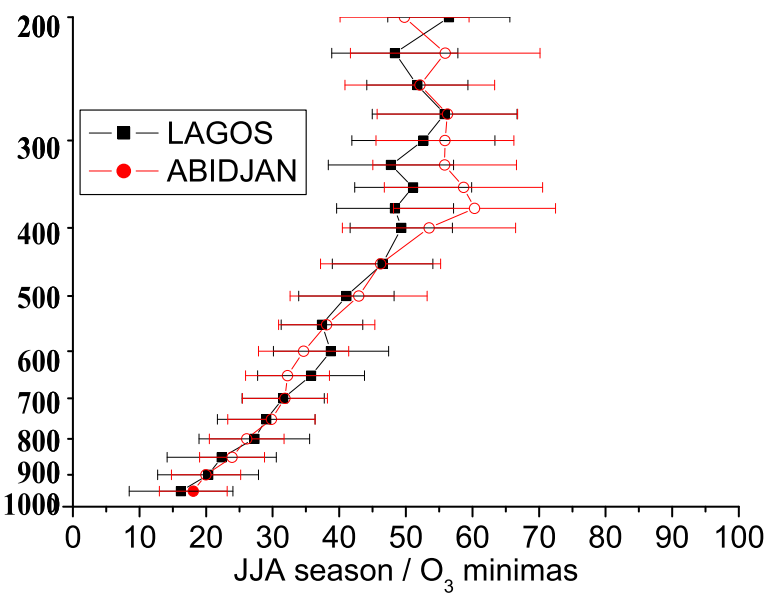

(b)

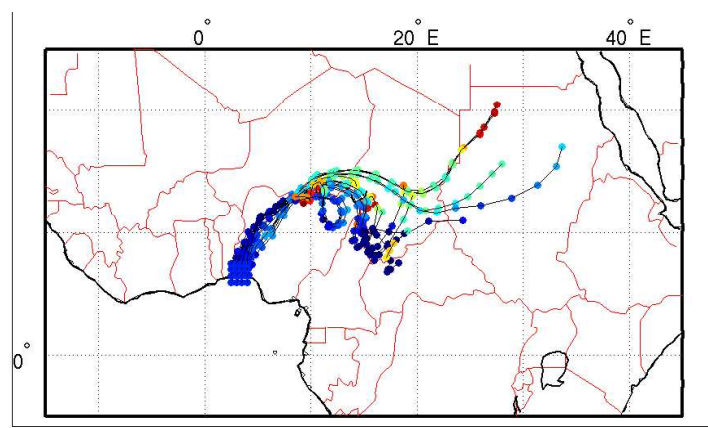

(d) 600

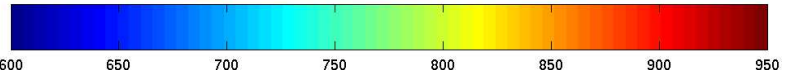

Fig. 15. Seasonal vertical profiles of ozone over Lagos (black) and Abidjan red, in JJA. Average with enhancement in the lower troposhere (a), without ozone enhancement (b). (c); (d): example of associated back-trajectories: (c) 11-16 July 2000; (d) 24-29 July 2000. 


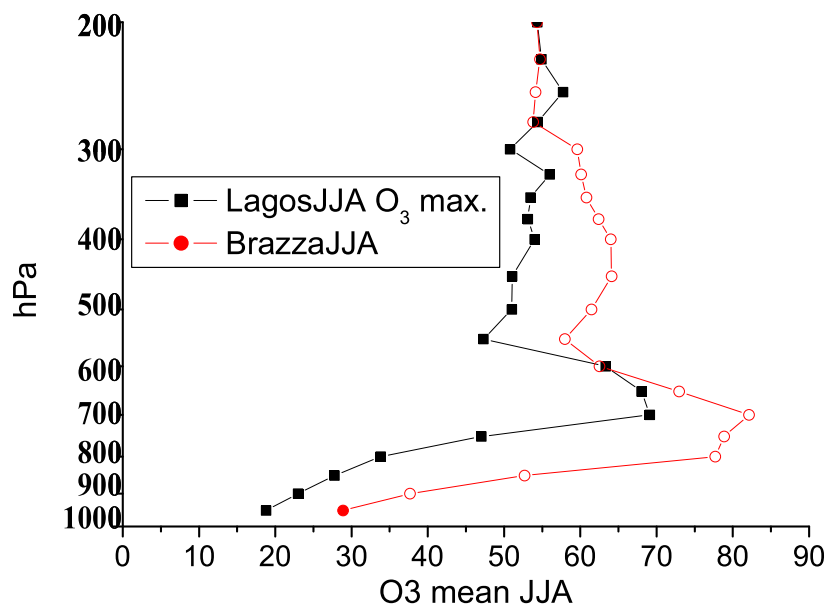

Fig. 16. Seasonal ozone vertical profiles over Lagos (black) and Brazzaville (red) during the Southern Hemisphere biomass burning season JJA

55 ppbv, Fig. 18e). In the upper levels, concentrations are similar in the two seasons at the three sites with about 5060 ppbv. The annual cycle shown in Fig. 19e exhibits the strong seasonal cycle in the lower troposphere with a maximum from November to March, while Figs. 19a and c clearly exhibit the noticeable characteristic of northern Equatorial Africa: absence of any strong seasonal variability in the middle and upper troposphere. This can be explained by the subsidence caused by the Saharan Anticyclone found near 500 $\mathrm{hPa}$ between $5^{\circ}-15^{\circ} \mathrm{N}$, which is present between November and February. Moreover, the stability of the Harmattan layers restricts ascending motions, and thus allows accumulation of pollutants in the lower troposphere by restricting ventilation into the upper levels.

\subsubsection{Central and East Africa}

During the intermediate season MAM, these regions do not exhibit any particular ozone feature. Concentrations are lower below $600 \mathrm{hPa}$ with less than $50 \mathrm{ppbv}$. In the middle troposphere concentrations may reach 50 ppbv (Figs. 17b, d and $\mathrm{f}$ ).

During SON, there is over Central Africa an extension of the seasonal maximum that starts in June, at both $750 \mathrm{hPa}$ (except over Brazzaville), $500 \mathrm{hPa}$ and $250 \mathrm{hPa}$ (Figs. 19b and d). Indeed, the vertical profiles (Fig. 18, right column) show three enhanced layers in September over Luanda. The first one centered at $650 \mathrm{hPa}$ with $100 \mathrm{ppbv}$, the second at $450 \mathrm{hPa}(85 \mathrm{ppbv})$ and the last one at $250 \mathrm{hPa}$ (75 ppbv). During October and November, there is just one thick layer with ozone mixing ratio up to $80 \mathrm{ppbv}$, centered near $350 \mathrm{hPa}$, and a large perturbation from the background $(+20 /+25$ ppbv $)$. Brazzaville shows a similar behaviour in October, with $70 \mathrm{ppbv}$ of ozone around $350 \mathrm{hPa}$.
This region has been much studied during the TRACE-A and SAFARI-92 campaigns that took place in SON season. At this time of the year, the dry season ends, with a maximum of biomass burning activity around the south-eastern countries of Africa (Mozambique, Zimbabwe, South Africa). Recirculation over Central Africa via the northern edge of the continental anticyclone could explain such high concentration over Luanda in September (Figs. 18b and 19f). Stable layers have been observed, around $600 \mathrm{hPa}$, and transport to higher levels has been explained by strong deep convective lifting, as described by Garstang et al. (1996), during SAFARI-92 campaign (August 16 to October 31). This may explain the stratified structure in August and September over Luanda. Easterly winds give then the rise to the advection of biomass burning ozone precursors from the eastern part of Africa (Malawi, Zimbabwe and Mozambique), after they have been transported vertically by convection into the middle troposphere over Brazzaville and Luanda. A similar fire influence has been observed by Thompson et al. (1996) and Jenkins et al. (1997), during the TRACE-A and SAFARI 92 campaigns and can explain the continuity of high ozone concentrations in both three levels of the troposphere, 750, 500 and $250 \mathrm{hPa}$, up to October (Fig 19f, d and b).

The other origin of the high ozone values during this season over Central Africa may be the biomass burning activity in Brazil. It is at its maximum during this period (Hao et al., 1994). Krishnamurti et al. (1996) have shown such an origin, especially in the upper troposphere over the Atlantic, where north-westerly and westerly transport predominates. Convection may lift ozone and its precursors from the boundary layer over Brazil to the middle and the upper troposphere, where it is transported over the Atlantic by highlevel westerlies, and with the easterlies emanating from the St-Helene high (SASTA) centered over Namibia (Browell et al., 1996). This enhancement in the middle troposphere during SON is also in agreement with the analyses made by Cros et al. (1992), Kirchhoff et al. (1996), Nganga et al. (1996), Thompson et al. (1996), Diab et al. (1996) and Olson et al. (1996) during the TRACE-A and SAFARI 92 campaigns.

Another attributable origin of the high ozone concentrations measured over Angola and Congo near $250 \mathrm{hPa}$ in SON may be the ozone production from lightning $\mathrm{NO}_{\mathrm{x}}$ emissions. Observations from space by the LIS sensor (http://thunder. msfc.nasa.gov/data/query/distributions.html) show high levels of lightning activity over Angola and Congo in SON, as well as during DJF (see Sect. 3.1). The impact of lightning $\mathrm{NO}_{\mathrm{x}}$ emissions on ozone production is badly quantified, as is the magnitude of the emissions. Estimates of the source magnitude are highly variable, from $3 \mathrm{Tg} \mathrm{N} \mathrm{yr}^{-1}$ to $10 \mathrm{Tg} \mathrm{N} \mathrm{yr}^{-1}$ (Jourdain and Hauglustaine, 2001; Staudt et al., 2002a). The uncertainty of the global $\mathrm{NO}_{\mathrm{x}}$ lightning source and its impact on ozone concentrations remain one of the major issues in understanding the tropical ozone budget. However, this region as well as West Africa and South Atlantic, is highly sensitive to such influence, because of subsidence throughout 


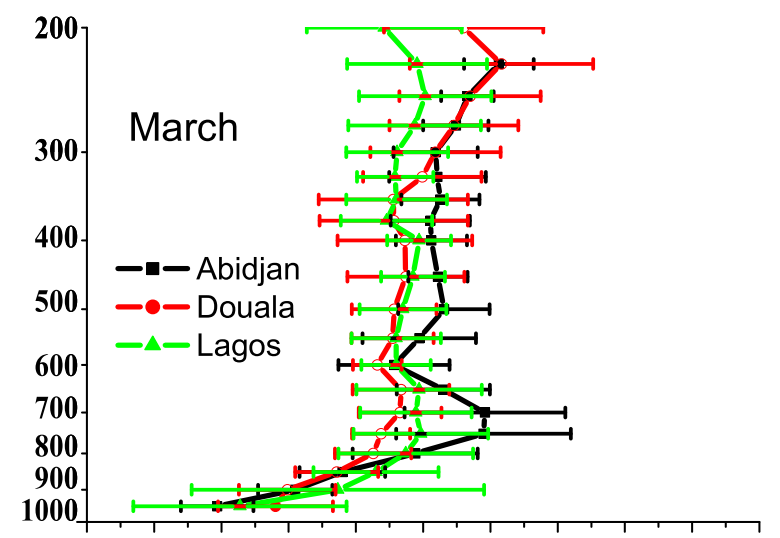

(a)
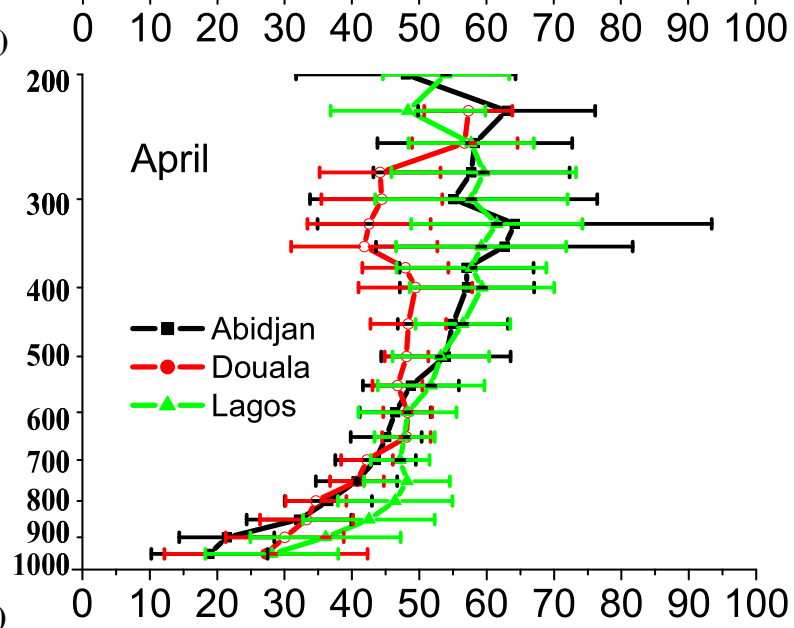

(b)
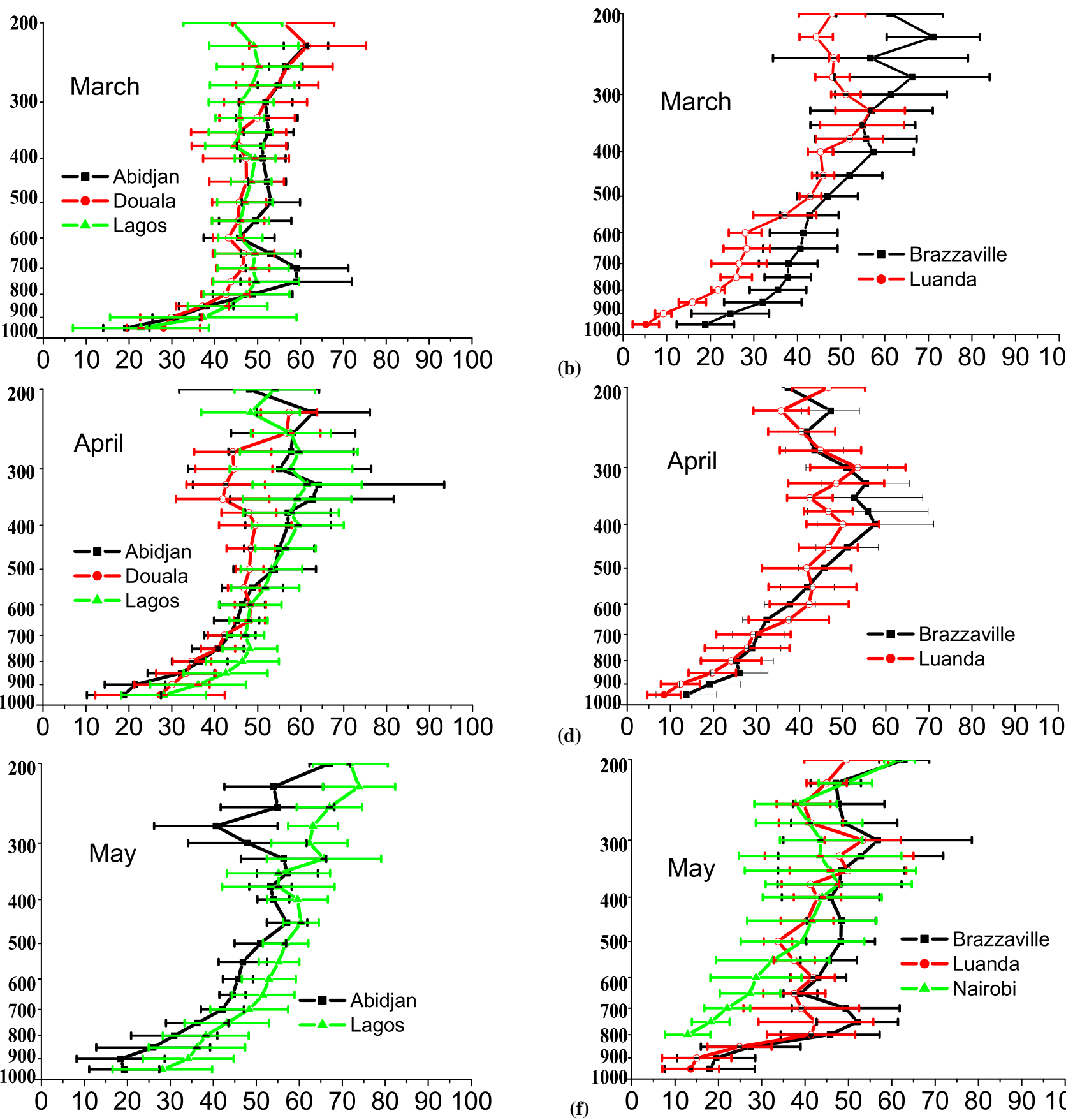

(d)

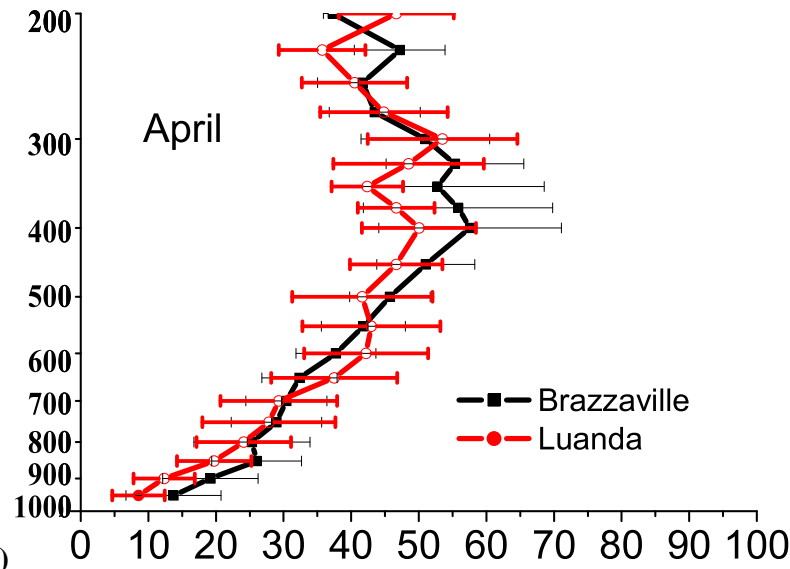

(e)

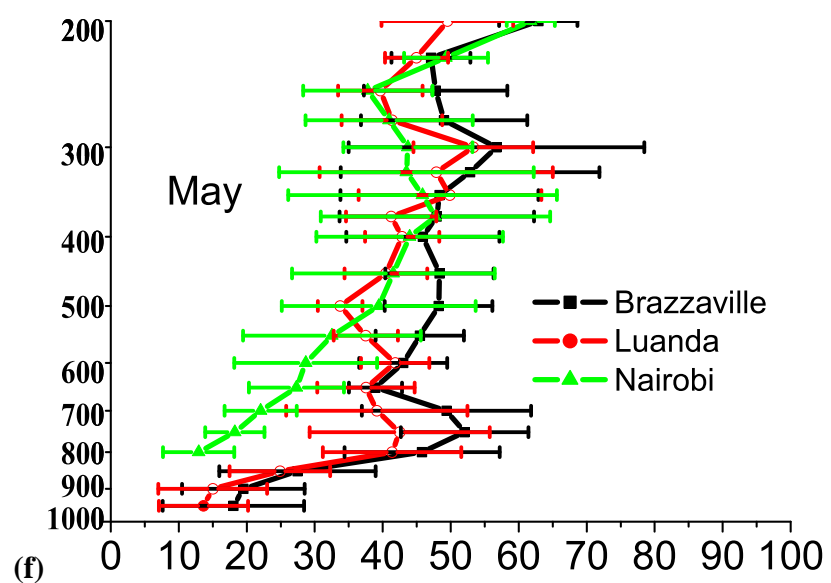

Fig. 17. Monthly mean ozone vertical profiles in parts per billion by volume (ppbv) as a function of pressure, over the different areas: for the Gulf of Guinea in March (a), April (c), May (e) with: Abidjan (black), Douala (red), Lagos (green); for the Central and East Africa in March (b), April (d), May (f) with: Brazzaville (black), Luanda (red), Nairobi (green). The horizontal bars represent one standard deviation about mean.

the year due to the Walker circulation (Jacob et al., 1996). For example, Martin et al. (2002) found a 10-15 DU TTOCs enhancement due to lightning over the tropical Atlantic.
Over East Africa, during SON season (and from JJA season), the amplitude of the seasonal cycle at $750 \mathrm{hPa}$ (Fig. 19f) is highly variable from one place to another. The airports are situated east, west and north of Lake Victoria (Fig. 3), with different vegetation. The lowest concentrations appear over this region. We note that the more continental the station, the 

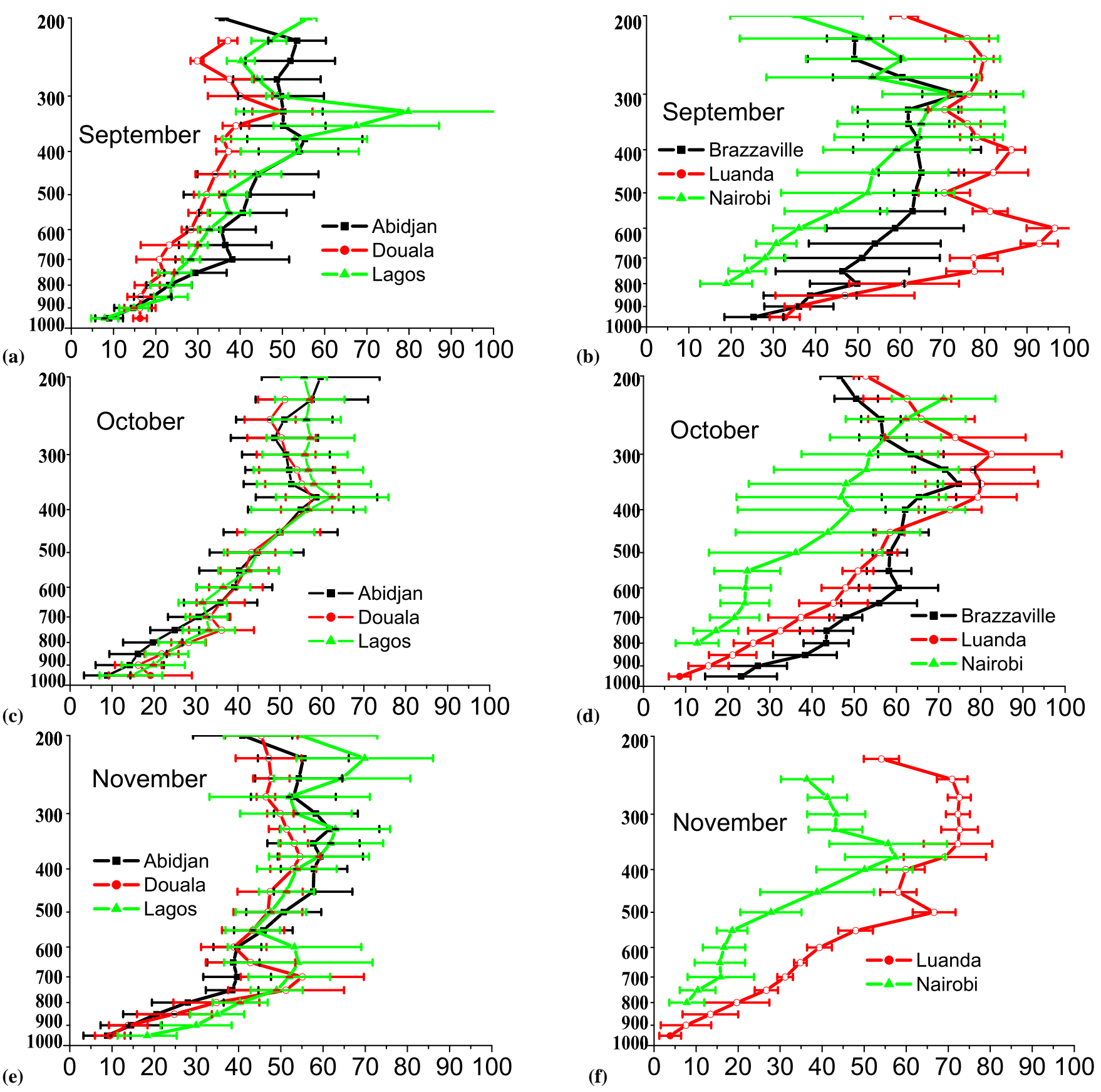

Fig. 18. Monthly mean ozone vertical profiles in parts per billion by volume (ppbv) as a function of pressure, over the different areas: for the Gulf of Guinea in September (a), October (c), November (e) with: Abidjan (black), Douala (red), Lagos (green); for the Central and East Africa in September (b), October (d), November (f) with: Brazzaville (black), Luanda (red), Nairobi (green). The horizontal bars represent one standard deviation about mean.

higher the ozone concentrations (minimum over Nairobi and maximum over Kigali). This shows that the major controlling factor is probably the proximity to surface continental emissions. During the dry season, as well as during JJA, layers with higher ozone are not observed as a mean, in contrast to Central Africa. Similar low concentrations are also mea- sured over Nairobi by the soudings from SHADOZ (Thompson et al., 2003a). In the lower troposphere, the oceanic origin of the south-easterlies may explain why the ozone values are lower over East Africa than over Central Africa. Despite the absence of such pronounced layers, ozone concentrations exhibit a seasonal cycle with a clear maximum at this 


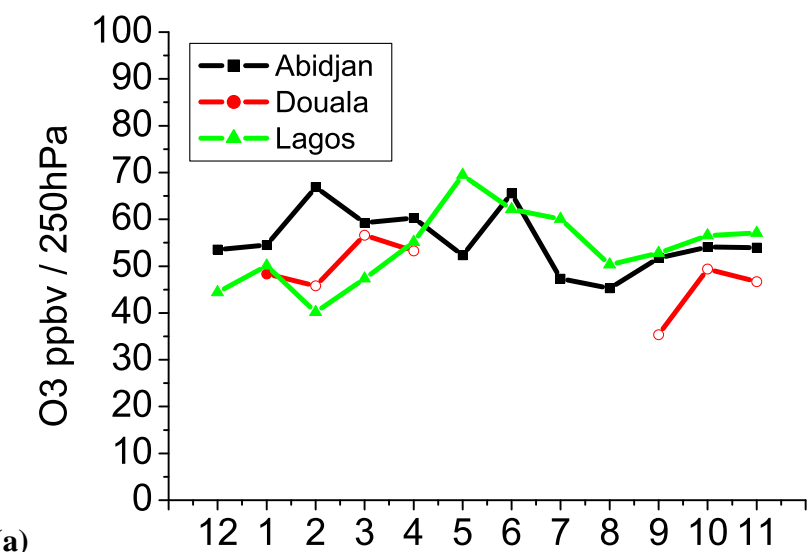

(a)

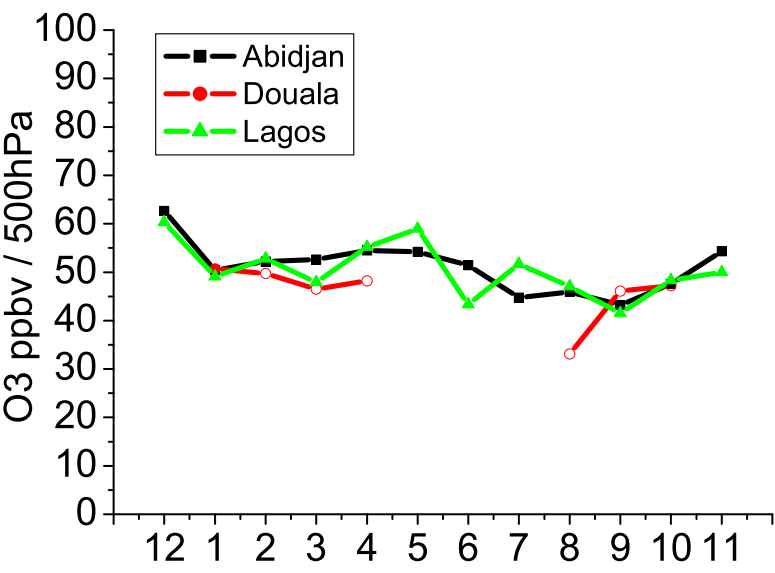

(b)
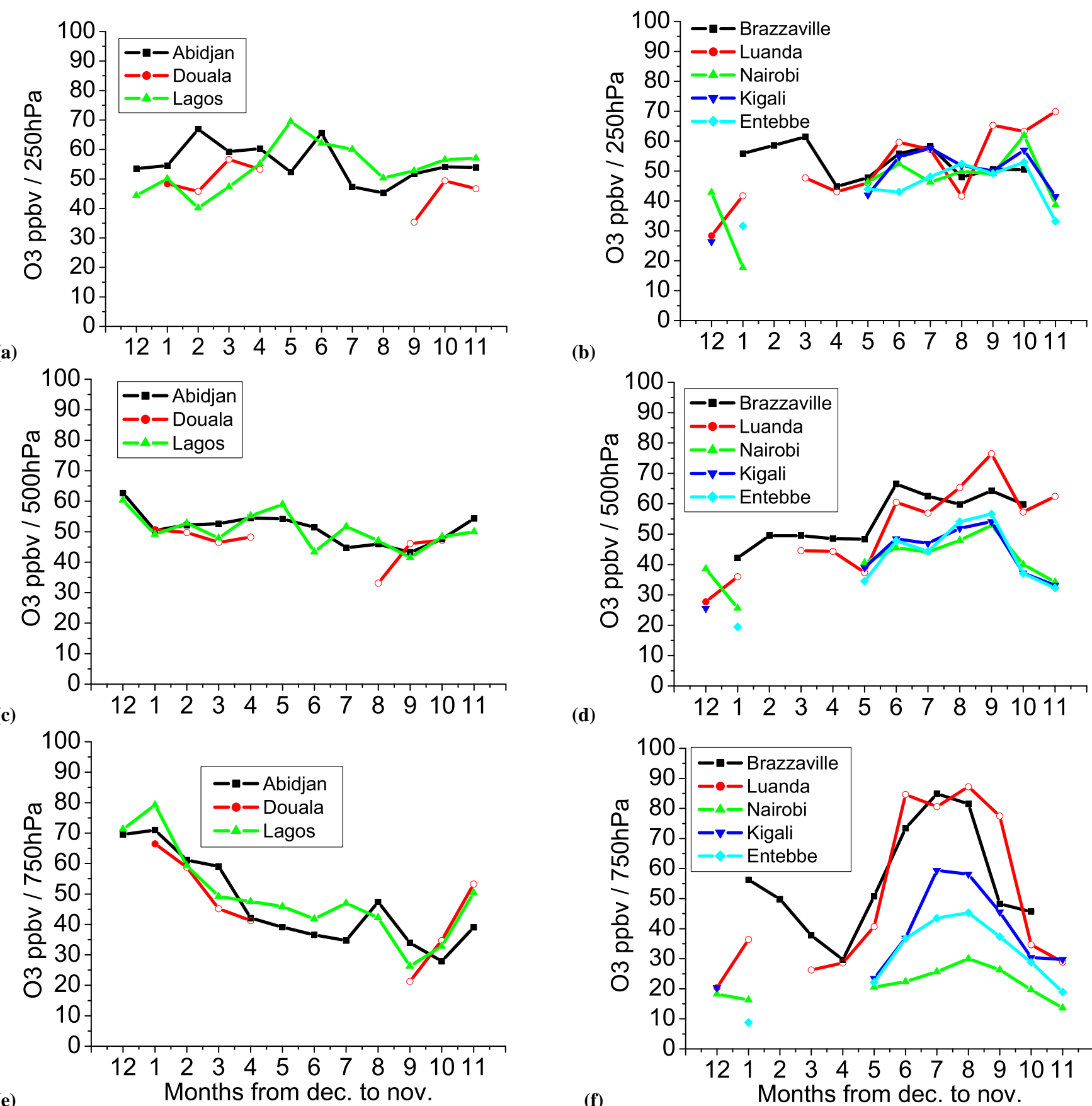

(d)

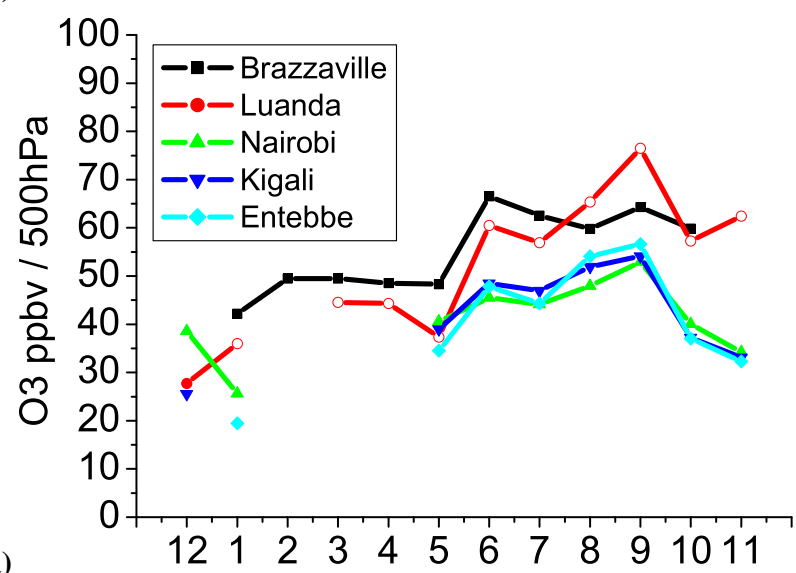
Months from dec. to nov.

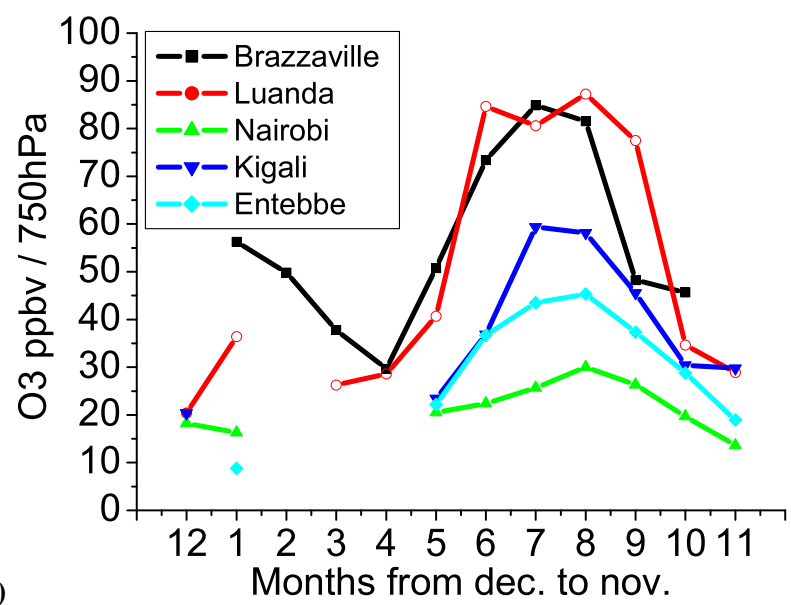

Fig. 19. Ozone seasonal cycles at $250 \mathrm{hPa}$ (a and b), $500 \mathrm{hPa}$ (c and d) and $750 \mathrm{hPa}$ (e and f) for the Gulf of Guinea stations (left) Abidjan in red, Douala in red, and Lagos in green; and those within the Southern Hemisphere (right) Brazzaville in black, Luanda in red, Nairobi in green, Kigali in blue and Entebbe in Cyan. Monthly means are from December to November averaged over the entire period (April 1997-March 2003).

time of the year (JJA), throughout the three levels (Fig. 19). Higher up in the troposphere, concentrations are more similar at the three sites, both at $500 \mathrm{hPa}$ and $250 \mathrm{hPa}$ (Figs. 19d and b). However, note that Chatfield et al. (2002) have observed more polluted air masses at $8 \mathrm{~km}$ (in September) over this region which can then be transported along the eastern coast of Africa into a low-pressure system over South Africa. Note that this region has the weakest MOZAIC data density, and therefore such strong pollution events can be missed. As stated previously, this region could also be influenced by long range transport from Indian Ocean (Chatfield et al., 2004). 


\section{Summary and conclusions}

More than 800 MOZAIC vertical profiles over Equatorial Africa, recorded between April 1997 and March 2003, provide a new and unique view of the tropospheric ozone distribution over this previously poorly documented region. Analyses of the ozone monthly mean vertical distributions combined with analyses of the most persistent dynamical features over different regions have shown:

- A connection in DJF between northern regions of fires and an observed ozone maximum over the Gulf of Guinea, with more than $80 \mathrm{ppbv}$ of ozone within a layer of about $150 \mathrm{hPa}$ thickness, centered near $800 \mathrm{hPa}$. This connection is due to transport in the Harmattan and is associated with ozone maxima extending downwind up to Congo.

- A connection during the same season, between northeastern regions of fires and ozone maximum over the Gulf of Guinea, due to a transport by the African Easterly Jet. This maximum is centered near $700 \mathrm{hPa}$. The absence of any zonal gradient suggests a slow photochemical production or strong mixing processes during the transport along the African Easterly Jet.

- A connection between southern regions of fires and ozone maximum over Luanda and Brazzaville, due to the inflowing trade winds during JJA. Thus Central Africa exhibits an ozone maxima centered near $800 \mathrm{hPa}$, with greater concentrations (up to $100 \mathrm{ppbv}$ ) than over the Gulf of Guinea in northern hemisphere dry season. Different types of vegetation with different emission factors may be responsible for these differences.

- A connection between southern regions of fires and ozone maxima over Gulf of Guinea, due to the Trades inflow in JJA season. This connection is the least persistent one, as it depends on the position of the ITCZ. Indeed a detailed analysis has shown that the ozone profiles during the summer monsoon period may be grouped in two different categories: loaded with pollution originating from the southern fires $(30 \%)$ or ozone depleted (50\%).

One of the particularities highlighted in this study is that the Gulf of Guinea exhibits no seasonal variation above $600 \mathrm{hPa}$ (monthly mean concentrations between 50 and $60 \mathrm{ppbv})$. The enhancement recorded in the lower troposphere in DJF remains confined between 800 and $650 \mathrm{hPa}$. This particular feature is due to the dynamical situation over West Africa. Indeed, the polluted layers are enclosed below the trade wind inversion, capped with subsiding warm air from high altitude, provided by the anticyclone. The stability of the Harmattan layer and the presence of the AEJ above prevents any efficient vertical transport. In contrast, the mid-troposphere over Central Africa presents a broad
June-November ozone maximum. Ozone distribution in the middle and upper troposphere shows various influences with regional or global origin, in agreement with observations from the TRACE-A and SAFARI 92 campaigns (Table 1) and more recently by Chatfield et al. (2004).

Finally the most interesting result of this study lies in the connection between the regions of Gulf of Guinea north of the Equator and Brazzaville to the south. This connection appears in the dry season of each hemisphere. During the northWest Africa monsoon (JJA), some of the vertical profiles recorded over the Gulf of Guinea exhibit enhanced ozone layers originating from the southern hemisphere fires. Symetrically the vertical distribution of ozone over regions of Congo (Brazzaville) in DJF clearly shows the influence of the northern hemisphere fires.

This study clearly suggests that the northern African tropics play an important role in the regional and global ozone budget. Perspectives of this study include the completion of a conceptual model that makes use of the continental African connections shown up in this paper, with the large zonal wave-one feature to explain the role of the large scale circulation in the ozone budget over this part of the globe. Indeed, studies made on TOMS and SHADOZ network data have highlighted that with regards to the global tropical ozone distribution a zonal wave-one feature (Thompson et al., 2003b) sits over the equatorial Atlantic and is accompanied by an "ozone paradox" (Thompson et al., 1999). However, limitations of the previous studies still persist as they are inherent in satellite sensors having weak capacities to capture deep tropospheric ozone features and inherent in the locations of SHADOZ sites that are mostly maritime and situated in the southern hemisphere.

Acknowledgements. The authors acknowledge MOZAIC funding agencies, the European Commission, CNRS (France), Forschungszentrum Jülich (Germany), Météo France, EADS (Airbus) and the airlines (Air France, Lufthansa, Austrian Airlines, and former Sabena who carry free of charge the MOZAIC equipment and perform the maintenance). We also acknowledge the ATSR World fire Atlas, European Agency, ESA/ERIN.

Edited by: A. Stohl

\section{References}

Andreae, M. O., Browel, A. V., Garstang, G. L., et al.: Biomass burning emissions and associated haze layers over Amazonia, J. Geophys. Res., 93, 1509-1527, 1988.

Andreae, M. O.: Biomass Burning: Its History, Use, and Distribution and its impact on Environmental Quality and Global Climate, in Biomass Burning and Global Change, Atmospheric, Climatic, and Biospheric Implications, edited by Levine, J. S., MIT Press, Cambridge, Massachusetts, 485-493, 1991.

Andreae, M. O., Chapuis, A., Cros, B., Fontan, J., Helas, G., Justine, C., Kaufman, Y. J., Minga, A., and Nganga, D.: Ozone and 
Aitken nuclei over equatorial Africa: Airborne observations during DECAFE 88, J. Geophys. Res., 97, 6137-6148, 1992.

Andreae, M. O., Anderson, B. E., Blake, D. R., Brashaw, J. D., Collins, J. E., Gregory, G. L., Sachse, G. W., and Shipham, M. C.: Influence of plumes from biomass burning on atmospheric chemistry over the equatorial and tropical South Atlantic during CITE 3, J. Geophys. Res., 99, 12 793-12 808, 1994.

Andreae, M. O., Atlas, E., Cachier, H., Cofer III, W. R., Harris, G. W., Helas, G., Koppmann, R., Lacaux, J. P., and Ward, D. E.: Trace gas and aerosol emissions from savanna fires, Biomass Burning and Global Change, edited by Levine, J. S., MIT Press, Cambridge, Mass., 278-295, 1996.

Browell, E. V., Fenn, M. A., Butler, C. F., Grant, W. B., Merrill, J. T., Newell, R. E., Bradshaw, J. D., Sandholm, S. T., Anderson, B. E., Bandy, A. R., Bachmeier, A. S., Blake, D. R., Davis, D. D., Gregory, G. L., Heikes, B. G., Kondo, Y., Liu, S. C., Rowland, F. S., Sachse, G. W., Singh, H. B., Talbot, R. W., and Thornton, D. C.: Large-scale air mass characteristics observed over Western Pacific during summertime, J. Geophys. Res., 101 (D1), 16911712, doi:10.1029/95JD02200, 1996.

Cautenet, S., Poulet, P., Delon, C., Delmas, R., Gregoire, J.-M., Pereira, J. M., Cherchali, S., Amram, O., and Flouzat, G.: Simulation of carbon monoxide redistribution over central Africa during biomass burning events (Experiment for Regional Sources and Sinks of Oxidants (EXPRESSO)), J. Geophys. Res., 104 (D23), 30 641-30 658, 1999.

Chatfield, R. B. and Delany, A. C.: Convection links biomass burning to increased tropical ozone: However, models will tend to overpredict $\mathrm{O}_{3}$, J. Geophys. Res., 95, D11, 18 473-18 488, 1990.

Chatfield, R. B., Vastano, J. A., Singh, H. B., Sachse, G.: A general model of how fire emissions and chemistry produce African/oceanic plumes $\left(\mathrm{O}_{3}, \mathrm{CO}, \mathrm{PAN}\right.$, smoke $)$ in TRACE-A, J. Geophys. Res., 101 (D19), 24 279-24 306, 1996.

Chatfield, R. B., Guan, H., Thompson, A. M., and Witte, J. C.: Convective lofting links Indian Ocean air pollution to paradoxical South Atlantic ozone maxima, Geophys. Res. Lett., 31, L06103, doi:10.1029/2003GL018866, 2004.

Cros, B., Nganga, D., Minga, A., Fishman, J., and Brackett, V.: Distribution of tropospheric ozone at Brazzaville, Congo, determined from ozonesondes measurements, J. Geophys. Res., 97, 12 869-12 875, 1992.

Crutzen, P. J.: Photochemical reaction initiated by an influencing ozone in unpolluted tropospheric air, Tellus, 26, 47-57, 1974.

Crutzen, P. J., Delany, A. C., Greenberg, J., Haagenson, P., Heidt, L., Lueb, R., Pollock, W., Seiler, W., Wartburg, A., and Zimmermann, P.: Tropospheric chemical composition measurements in Brazil during the dry season, J. Atm. Chem., 2, 233-256, 1985.

Crutzen, P. J.: The role of the tropics in atmospheric chemistry, The Geophysiology of Amazonia, edited by Dickinson, R. E., John Wiley, New York, 107-130, 1987.

Crutzen, P. J.: Tropospheric ozone: An overview, Tropospheric ozone, edited by: Isaksen, I. S. and Reidel, D., Norwell, Mass., 3-32, 1988 .

Crutzen, P. J. and Andreae, M. O.: Biomass burning in the tropics: impact on atmospheric chemistry and biogeochemical cycles, Science, 250, 1669-1678, 1990

Delmas, R. A., Loudjani, P., Podaire, A., and Menaut, J.-C.: Biomass burning in Africa: an assessment of annually burnt biomass, Global Biomass Burning Atmospheric, Climatic and
Biospheric Implications, edited by: Levine, J. S., MIT Press. Cambridge, Mass., 126-132, 1991.

Delmas, R. A., Druilhet, A., Cros, B., Durand P., et al.: Experiment for Regional Sources and Sinks of Oxidants (EXPRESSO): An overview, J. Geophys. Res., 104, 30 609-30 624, 1999.

Diab, R. D., Thompson, A. M., Zunckel, M., et al.: Vertical ozone distribution over southern Africa and adjacent oceans during SAFARI-92, J. Geophys. Res., 101, 23 823-23 835, 1996.

Duncan, B. N., Martin, R. V., Staudt, A. C., Yevich, R., and Logan, J. A.: Interannual and seasonal variability of biomass burning emissions constrained by satellite observations, J. Geophys. Res., 108, D2, 4100, doi:10.1029/2002JD002378, 2003.

Edwards, D. P., Lamarque, J. F., Attié, J. L., Emmons, L. K., Richter, A., Cammas, J. P., Gille, J. C., Francis, G. L., Deeter, M. N., Warner, J., Ziskin, D. C., Lyjak, L. V., Drummond, J. R., and Burrows, J. P.: Tropospheric Ozone Over the Tropical Atlantic: A Satellite Perspective, J. Geophys. Res., 108 (D8), 4237, doi:10.1029/2002JD002927, 2003.

Findlater, J.: The low-level cross-equatorial air current of the Western Indian Ocean during the northern summer, Weather, 29, 411416, 1974.

Fishman, J., Solomon, S., and Crutzen, P. J.: Observational and theoretical evidence in support of a significant in situ photochemical source of tropospheric ozone, Tellus, 31, 432-446, 1979.

Fishman, J., Watson, C. E., Larsen, J. C., and Logan, J. A.: Distribution of tropospheric ozone determined from satellite data, J. Geophys. Res., 95, 3599-3617, 1990.

Fishman Jr., J., Bendura, R. D., McNeal, R. J., and Kirchhoff, V. W. J. H.: NASA GTE TRACE A Experiment (September-October 1992): Overview, J. Geophys. Res., 101, 23 865-23 880, 1996.

Fishman, J. and Brackett, V. G.: The climatological distribution of tropospheric ozone derived from satellite measurements using version 7 Total Ozone Mapping Spectrometer and Stratospheric Aerosol and Gas Experiment data set, J. Geophys. Res., 102, 19275-19278, 1997.

Fontan, J., Druilhet, A., Benech, B., Lyra, R., and Cros, B.: The DECAFE Experiments: Overview and Meteorology, J. Geophys. Res., 97, 6123-6136, 1992.

Fuelberg, H. E., Van Ausdall, J. D., Browell, E. V., and Logmore, S P.: Meteorogical conditions associated with vertical distributions of aerosols off the west coast of Africa, J. Geophys. Res., 101, 24 105-24 115, 1996.

Garstang, M., Tyson, P. D., Sap, R., Edwards M., Kallberg P., and Lindesay, J. A.: Horizontal and vertical transport of air over southern Africa, J. Geophys. Res., 101, 23 721-23 736, 1996.

Hao, W. M. and Liu, M. H.: Spatial and temporal distribution of tropical biomass burning, Global Biogeochem. Cycles, 8, 495503, 1994.

Hastenrath, S.: Climate Dynamics of the Tropics, Kluwer Acad. Norwell, Mass., 488, 1991.

Jacob, D. J., Heikes, B. G., Fan, S.-M., Logan, J. A., Mauzerall, D. L., Bradshaw, J. D., Singh, H. B., Gregory, G. L., Talbot, R. W., Blake, D. R., and Sachse, G. W. : Origin of ozone and $\mathrm{NO}_{\mathrm{x}}$ in the tropical troposphere: A photochemical analysis of aircraft observations over the South Atlantic basin, J. Geophys. Res., 101, 24 235-24 250, 1996.

Jenkins, G. S., Mohr, K., Morris, V. R., and Arino, O.: The role of convective processes over the Zaire and Congo Basins to the Southern Hemisphere ozone maximum, J. Geophys. Res., 102, 
18963-18 980, 1997.

Jenkins, G. S. and Ryu, J.-H.: Space-borne observations link the tropical Atlantic ozone maximum and paradox to lightning, Atmos. Chem. Phys., 4, 361-375, 2004a,

SRef-ID: 1680-7324/acp/2004-4-361.

Jenkins, G. S. and Ryu, J.-H.: Linking horizontal and vertical transports of biomass fire emissions to the tropical Atlantic ozone paradox during the Northern Hemisphere winter season: climatology, Atmos. Chem. Phys., 4, 449-469, 2004b,

SRef-ID: 1680-7324/acp/2004-4-449.

Jonquieres, I., Marenco, A., and Maalej, A.: Study of ozone formation and trans-atlantic transport from biomass burning emissions over West Africa during the airborne campaigns TROPOZ I and TROPOZ II, J. Geophys. Res., 103, D15, 19 059-19 073, 1998.

Jourdain, L. and Hauglustaine, D. A.: The global distribution of lightning $\mathrm{NO}_{\mathrm{x}}$ simulated on-line in a general circulation model, Phys. Chem. Earth Part C, 26, 585-591, 2001.

Kim, J. H., Newchurch, M. J., and Han, K.: Distribution of tropical tropospheric ozone determined by the scan-angle method applied to TOMS measurements, J. Atmos. Sci., 58, 2699-2708, 2001.

Kirchhoff, V. W. J. H., Alves, J. R., Da Silva, F. R., and Fishman, $\mathrm{J}$. : Observations of ozone concentrations in the Brazilian cerrado during the TRACE A field expedition, J. Geophys. Res., 101, 24 029-24 042, 1996.

Krishnamurti, T. N., Sinha, M. C., Kanamitsu, M., Oosterhof, D., Fuelberg, H., Chatfield, R. B., Jacob, D. J. and Logan, J.: Passive tracer transport relevant to the TRACE A experiment, J. Geophys. Res., 101, 23 889-23 907, 1996.

Lelieveld, J., Crutzen, P. J., Ramanathan, V., et al.: The Indian Ocean Experiment: Widespread air pollution from South and Southeast Asia, Science, 291, 1031-1036, 2001.

Lindesay, J. A., Andreae, M. O., Goldammer, J. G., Harris, G., Annegarn, H. J., Garstang, M., Scholes, R. J., and van Wilgen, B. W.: International Geosphere-Biosphere Programme/International Global Atmospheric Chemistry SAFARI92 field experiment: Background and overview, J. Geophys. Res., 101, 23 521-23 530, 1996.

Logan, J. A., Prather, M. J., Wofsy, S. C., and Mc Elroy, M. B.: Tropospheric chemistry: A global perspective, J. Geophys. Res., 86, 7210-7254, 1981.

Logan, J. A.: Tropospheric ozone: Seasonal behavior, trends and anthropogenic influence, J. Geophys. Res., 90, 10 463-10482, 1985.

Logan, J. A. and Kirchhoff, V. W. J. H.: Seasonal variations of tropospheric ozone at Natal, Brazil, J. Geophys. Res., 91, 78757888, 1986.

Logan, J. A.: An analysis of ozonesondes data for the troposphere: Recommendations for testing 3-D models and development of a gridded climatology for tropospheric ozone, J. Geophys. Res., 104, 16 115-16 149, 1999.

Marenco, A., Macaigne, M., and Prieur, S.: Meridional and vertical $\mathrm{CO}$ and $\mathrm{CH}_{4}$ distributions in the background troposphere $\left(70^{\circ} \mathrm{N}-60^{\circ} \mathrm{S} ; 0-12 \mathrm{~km}\right.$ altitude) from scientific aircraft measurements during the STRATOZ III experiment (June 1984), Atmos. Environ., 23, 185-200, 1989.

Marenco, A., Medale, J. C., and Prieur, S.: Study of tropospheric ozone in the tropical belt (Africa, America) from STRATOZ and TROPOZ campaigns, Atmos. Environ., Part A, 24, 2823-2834, 1990.
Marenco, A., Thouret, V., Nedelec, P., Smit, H. G., Helten, M., Kley, D., Karcher, F., Simon, P., Law, K., Pyle, J., Poschmann, G., Von Wrede, R., Hume, C., and Cook, T.: Measurement of ozone and water vapor by Airbus in-service aircraft: The MOZAIC airborne program, an overview, J. Geophys. Res., 103, 25 631-25 642, 1998.

Martin, R. V., Jacob, D. J., Logan, J. A., Bey, I., Yantosca, R. M., Staudt, A. C., Li, Q. B., Fiore, A. M., Duncan, B. N., Liu, H. Y., Ginoux, P., and Thouret, V.: Interpretation of TOMS observations of tropical tropospheric ozone with a global model and in situ observations, J. Geophys. Res., 107, D18, 4351, doi:10.1029/2001JD001480, 2002.

Nedelec, P., Cammas, J.-P., Thouret, V., Athier, G., Cousin, J.-M., Legrand, C., Abonnel, C., Lecoeur, F., Cayez, G., and Marizy, C.: An improved infrared carbon monoxide analyser for routine measurements aboard commercial Airbus aircraft: technical validation and first scientific results of the MOZAIC III programme, Atmos. Chem. Phys., 3, 1551-1564, 2003,

SRef-ID: 1680-7324/acp/2003-3-1551.

Nganga, D., Minga, A., Cros, B., Bouka Biona, C., Fishman, J., and Grant, W. B.: The vertical distribution of ozone measured at Brazzaville, Congo during TRACE A, J. Geophys. Res., 101, 24 095-24 103, 1996.

Olson, J. R., Fishman, J., Kirchhoff, V. W. J. H., Nganga, D., and Cros, B.: Analysis of the distribution of ozone over the southern Atlantic region, J. Geophys. Res., 101, 24 083-24 093, 1996.

Singh, H. B., Herlth, D., Kolyer, R., et al.: Impact of biomass burning emissions on the composition of the South Atlantic troposphere: Reactive nitrogen and ozone, J. Geophys. Res., 101, 24 203-24 219, 1996.

Stoller, P., Cho, J., Newel, R., et al.: Measurements of atmospheric layers from the NASA DC-8 and P-3B aircraft during PEMTropics A, J. Geophys. Res., 104, 5745-5764, 1999.

Staudt, A. C., Jacob, D. J., Logan, J. A., Bachiochi, D., Krishnamurti, T. N., and Poisson, N.: Global Chemical model analysis of biomass burning and lightning influences over the South Pacific in austral spring, J. Geophys. Res., 107, D14, 4200, doi:10.1029/2000JD000296, 2002.

Swap, R. J., Annergarn, H. J., Suttles, J. T., King, M. D., Platnick, S., Privette, J. L., and Scholes, R. J.: Africa burning: A thematic analysis of the Southern African Regional Science Initiative (SAFARI 2000), J. Geophys. Res., 108, D13, doi:10.1029/2003JD003747, 2003.

Thompson, A. M.: The oxidizing capacity of the earth's atmosphere: Probable past and future changes, Science, 256, 1157 1165, 1992.

Thompson, A. M., Pickering, K. E., McNamara, D. P., Schoeberl, M. R., Hudson, R. D., Kim, J. H., Browell, E. V., Kirchhoff, V. W. J. H., and Nganga, D.: Where did tropospheric ozone over southern Africa and the tropical Atlantic come from in October 1992?, Insights from TOMS, GTE/TRACE-A and SAFARI-92, J. Geophys. Res., 101, 24 251-24 278, 1996.

Thompson, A. M., Doddridge, B. G., Witte, J. C., Hudson, R. D., Luke, W. T., Johnson, J. E., Johnson, B. J., Oltmans, S. J., and Weller, R.: A tropical atlantic paradox: shipboard and satellite views of a tropospheric ozone maximum and wave-one in January-February 1999, Geophys. Res. Lett., 27, 3317-3320, 2000. 
Thompson, A. M., Oltmans, S. J., Schmidlin, F. J., Logan, J. A., Fuliwara, M., Kirchhoff, V. W. J. H., Posny, F., Coetzee, G. J. R., Hoegger, B., Kawakami, S., Ogawa, T., Johnson, B. J., Vomel, H., and Labow, G.: Southern Hemisphere Additional Ozonesondes (SHADOZ) 1998-2000 tropical ozone climatology 1. Comparison with Total Ozone Mapping Spectrometer (TOMS) and ground-based measurements, J. Geophys. Res., 108, D2, 8238, doi:10.1029/2001JD000967, 2003a.

Thompson, A. M., Oltmans, S. J., Schmidlin, F. J., Logan, J. A., Fuliwara, M., Kirchhoff, V. W. J. H., Posny, F., Coetzee, G. J. R., Hoegger, B., Kawakami, S., Ogawa, T., Johnson, B. J., Vomel, H., and Labow, G.: The 1998-2000 SHADOZ Tropical Ozone Climatology, 2. Stratospheric and tropospheric ozone variability and the zonal wave-one, J. Geophys. Res., 108, D2, 8241, doi:10.1029/2002JD002241, 2003b.

Thouret, V., Marenco, A., Nedelec, P., and Grouhel, C.: Ozone climatologies at $9-12 \mathrm{~km}$ altitude as seen by the MOZAIC airborne program between September 1994 and August 1996, J. Geophys. Res., 103, D19, 25 653-25 679, 1998a.
Thouret, V., Marenco, A., Logan, J., Nedelec, P., and Grouhel, C.: Comparisons of ozone measurements from the MOZAIC airborne program and the ozone sounding network at eight locations, J. Geophys. Res., 103, 25 695-25 720, 1998b.

Volz-Thomas, A., Berg, M., Heil, T., Houben, N., Lerner, A., Petrick, W., Raak, D., and $\mathrm{P}$ atz, H.: Measurements of total odd nitrogen $\left(\mathrm{NO}_{\mathrm{y}}\right)$ aboard MOZAIC in-service aircraft: instrument design, operation and performance, Atmos. Chem. Phys. Discuss., 4, 6149-6183, 2004,

SRef-ID: 1680-7375/acpd/2004-4-6149.

Wernli, H. and Davies, H. C.: A Lagrangian-based analysis of extratropical cyclones, I: The method and some applications, Q. J. R. Meteorol. Soc., 123, 467-489, 1997.

Wernli, H.: A Lagrangian-based analysis of extratropical cyclones, II: A detailed case study, Q. J. R. Meteorol. Soc., 123, 16771706, 1997. 